University of Nebraska - Lincoln

DigitalCommons@University of Nebraska - Lincoln

\title{
Dynamics of Plains Cottonwood (Populus deltoides) Forests and Historical Landscape Change along Unchannelized Segments of the Missouri River, USA
}

\author{
Mark D. Dixon \\ University of South Dakota, Mark.Dixon@usd.edu \\ W. Carter Johnson \\ South Dakota State University, carter.johnson@sdstate.edu \\ Michael L. Scott \\ U.S. Geological Survey \\ Daniel E. Bowen \\ Benedictine College \\ Lisa A. Rabbe \\ U.S. Army Corps of Engineers
}

Follow this and additional works at: https://digitalcommons.unl.edu/usgsstaffpub

Dixon, Mark D.; Johnson, W. Carter; Scott, Michael L.; Bowen, Daniel E.; and Rabbe, Lisa A., "Dynamics of Plains Cottonwood (Populus deltoides) Forests and Historical Landscape Change along Unchannelized Segments of the Missouri River, USA" (2012). USGS Staff -- Published Research. 730.

https://digitalcommons.unl.edu/usgsstaffpub/730

This Article is brought to you for free and open access by the US Geological Survey at DigitalCommons@University of Nebraska - Lincoln. It has been accepted for inclusion in USGS Staff -- Published Research by an authorized administrator of DigitalCommons@University of Nebraska - Lincoln. 


\title{
Dynamics of Plains Cottonwood (Populus deltoides) Forests and Historical Landscape Change along Unchannelized Segments of the Missouri River, USA
}

\author{
Mark D. Dixon - W. Carter Johnson • \\ Michael L. Scott • Daniel E. Bowen • \\ Lisa A. Rabbe
}

This article is a U.S. government work, and is not subject to copyright in the United States.

Received: 2 June 2011/Accepted: 29 February 2012 / Published online: 4 April 2012

(C) Springer Science+Business Media, LLC 2012

\begin{abstract}
Construction of six large dams and reservoirs on the Missouri River over the last 50-75 years has resulted in major landscape changes and alterations in flow patterns, with implications for riparian forests dominated by plains cottonwood (Populus deltoides). We quantified changes in land cover from 1892-1950s and the 1950s2006 and the current extent and age structure of cottonwood forests on seven segments (two reservoir and five remnant floodplain) comprising $1127 \mathrm{~km}(53 \%)$ of the unchannelized upper two-thirds of the Missouri River. Riparian forest area declined by $49 \%$; grassland $61 \%$; shrubland $52 \%$; and sandbar habitat $96 \%$; while agricultural cropland increased six-fold and river/reservoir surface area doubled from 1892 to 2006 . Net rates of erosion and accretion declined between the 1892-1950s and 1950s2006 periods. Accretion exceeded erosion on remnant floodplain segments, resulting in declines in active channel width, particularly in 1950s-2006. Across all study
\end{abstract}

\author{
M. D. Dixon ( $\square)$ \\ Department of Biology, University of South Dakota, \\ Vermillion, SD 57069, USA \\ e-mail: Mark.Dixon@usd.edu \\ W. C. Johnson \\ Department of Natural Resource Management, \\ South Dakota State University, Brookings, SD 57007, USA \\ M. L. Scott \\ U.S. Geological Survey, Fort Science Center, Fort Collins, \\ CO 80526, USA \\ D. E. Bowen \\ Department of Biology, Benedictine College, Atchison, \\ KS 66002, USA \\ L. A. Rabbe \\ U.S. Army Corps of Engineers, Kansas City, MO 64106, USA
}

segments in 2006, most cottonwood stands $(67 \%)$ were $>50$ years old, $22 \%$ were $25-50$ years old, and only $10 \%$ were $<25$ years old. Among stands $<50$ years old, the higher proportion of $25-50$ year old stands represents recruitment that accompanied initial post-dam channel narrowing; while declines in sandbar and shrubland area and the low proportion of stands $<25$ years old suggest declines in geomorphic dynamism and limited recruitment under recent river management. Future conservation and restoration efforts should focus both on limiting further loss of remnant cottonwood stands and developing approaches to restore river dynamics and cottonwood recruitment processes.

Keywords Riparian vegetation - Flow regulation · Dams $\cdot$ Channel change $\cdot$ Great Plains

\section{Introduction}

Most large rivers in the Northern Hemisphere have been modified by infrastructure designed to manage water resources (Dynesius and Nilsson 1994; Graf 1999; Nilsson and others 2005), permanently inundating large areas of former floodplain and significantly affecting downstream flows, geomorphic processes, and biota (Nilsson and Berggren 2000; Graf 2006; Poff and others 2007). On some rivers, bank stabilization structures disconnect the river from its floodplain and limit channel dynamics (Gergel and others 2002; Florsheim and others 2008; Michalková and others 2010; Ollero 2010). Protected from flooding by dams, levees, and incised channels, former flood-prone lands become suitable for agricultural or urban development, fragmenting or obliterating riparian ecosystems (e.g., Ollero 2010). 
In North America and worldwide, riparian forests composed of hydric, pioneer tree species, such as species of Populus (cottonwoods) and Salix (willows), are sensitive to the effects of flow regulation (Johnson and others 1976; Karrenberg and others 2002; Rood and others 2005). Floods help maintain the ecological health of these forests by providing moisture that sustains plant growth, depositing fine sediments and nutrients that enhance soil fertility, stimulating decomposition, dispersing seeds, and forming sediment bars that provide seedbeds for establishing new stands (Johnson and others 1976; Reily and Johnson 1982; Molles and others 1998; NRC 2002). In turn, riparian vegetation colonization interacts with and influences geomorphic processes in alluvial river channels and floodplains (Murray and others 2008; Corenblit and others 2009; Bertoldi and others 2011; Rood and others 2011). Because of multiple modes of cottonwood recruitment under different geomorphic contexts (Scott and others 1996; Cooper and others 2003; Stella and others 2011), effects of flow regulation can lead to varying effects on cottonwood dynamics on different rivers and river reaches. Post-dam declines in recruitment have been documented on meandering river reaches due to reductions in lateral migration and point bar formation (Johnson and others 1976; Rood and Mahoney 1990; Johnson 1992) and from reductions in overbank flooding and deposition on geologically constrained reaches (Scott and others 1996, 1997). In contrast, flow modification can lead to transient increases in cottonwood recruitment on some (e.g., braided) river reaches through colonization of the active channel bed and channel narrowing (Johnson 1994, 1998; Friedman and others 1998; Cooper and others 2003) or through colonization of abandoned channels formed by cutoff events (Stella and others 2011).

The Missouri River drains a large portion of the semiarid American West and historically sustained a diverse riparian landscape of wetlands, prairies, and floodplain forests, through an otherwise largely tree-less region (Finch and Ruggiero 1993). Plains cottonwood (Populus deltoides Marsh. Subsp. monilifera (Ait.) Eckenw.) was the foundational species in the riparian forests along the Missouri, sustained by a dynamic river channel that continually created open substrates for colonization and floods that recharged floodplain soil moisture, transported sediment, and dispersed seeds.

Major changes in flows and the riparian landscape accompanied large-scale development of infrastructure for flood control, hydroelectric power, and transportation on the Missouri River in the mid-20th century. Six large mainstem dams and reservoirs were constructed on the upper two-thirds of the basin in the 1930s-1960s, and nearly $1,200 \mathrm{~km}$ of stabilized channel and leveed floodplain were developed on the lower river (Schneiders 1999; NRC 2002). Losses of floodplain and riverine habitat under the reservoirs and alteration of flow and sediment processes downstream are blamed for a host of natural resource problems, including a lack of sandbar nesting habitat for endangered shore birds, poor spawning and recruitment conditions for native river fishes, reductions in nesting habitat for the Bald Eagle (Haliaeetus leucocephalus), and declines in cottonwood recruitment (NRC 2002).

Management and planning efforts are underway to mitigate for habitat losses, recover threatened species, and restore intact ecosystems (e.g., Missouri River Recovery Program, http://www.moriverrecovery.org/). This project was conducted to inform these efforts by documenting historical reference conditions for the Missouri River landscape; assessing the degree to which current conditions diverge from this reference; quantifying current forest age distribution, composition, and extent; and evaluating the implications of these for future forest trajectories and restoration actions along the unchannelized reaches of the Missouri River, upstream of Ponca, Nebraska (Fig. 1). In particular, findings will inform efforts by the U.S. Army Corps of Engineers to develop and implement plans for mitigating habitat loss and restoring cottonwood forests, in accordance with mandates to protect Bald Eagle habitat under the Endangered Species Act (USFWS 2003). Our specific aims were to quantify (1) current (2006) and historical (1892, 1950s) land cover patterns and their responses to important drivers of landscape change within the historical floodplain and (2) the extent and age distribution of riparian forests, particularly those containing cottonwood as a dominant species.

\section{Study Area}

The Missouri River basin occupies $1,396,117 \mathrm{~km}^{2}$, draining about one-sixth of the conterminous United States and portions of Canada. The river traverses a wide range of climatic, topographic, and ecological conditions, crossing three physiographic divisions (Rocky Mountains, Interior Plains, Interior Highlands) and thirteen terrestrial ecoregions between its origin at the junction of the Gallatin, Madison, and Jefferson rivers near Three Forks, Montana and its confluence with the Mississippi River near St. Louis, Missouri, 3,768 river km away (Fenneman and Johnson 1946; Ricketts and others 1999; Galat and others 2005). Ecoregions traversed (from northwest to southeast) include coniferous forests in the Rocky Mountain headwaters; shrub-steppe; shortgrass, mixed grass, and tallgrass prairies in the Great Plains; and mixed hardwood forests in the Central Lowlands. Today, agriculture occupies $37 \%$ of the basin, with $30 \%$ in grassland, $13 \%$ in shrub, $11 \%$ in forest, and $9 \%$ developed (Revenga and others 1998). Seventy percent of the basin is in the Great Plains, with a 
Fig. 1 Study segment numbers and major dams. Reservoir segments are shown in light blue. remnant floodplain segments in red, and locations of major dams in black

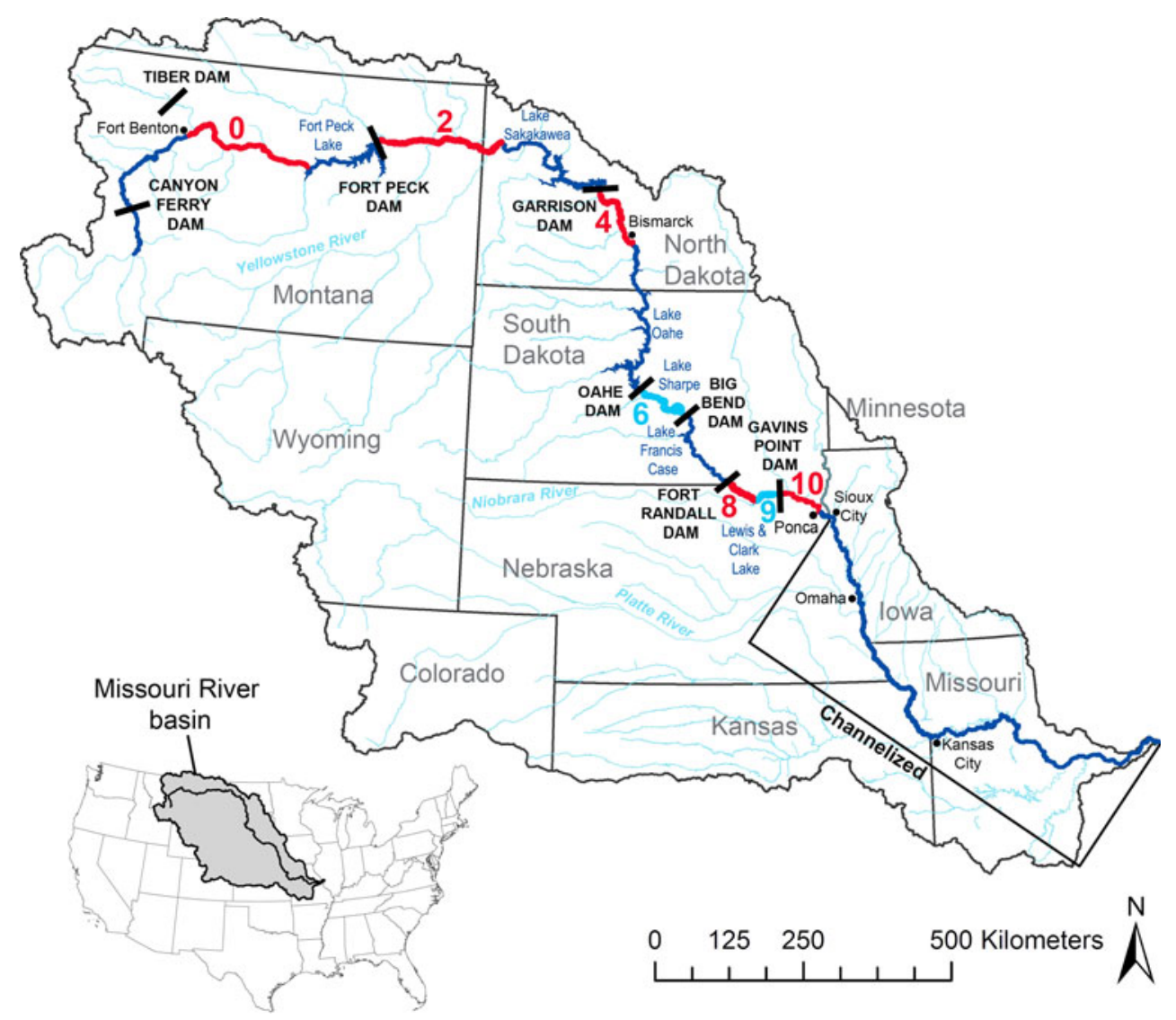

semi-arid continental climate characterized by high seasonal variability in weather, cold winters, and warm summers. Average annual precipitation across the basin ranges from 36 to $104 \mathrm{~cm} /$ year, with average precipitation less than $41 \mathrm{~cm}$ in approximately half of the basin, and $70 \%$ occurring during the growing season (Galat and others 2005).

Prior to extensive modification, the river was geomorphically dynamic and diverse, with a shifting sand-bed channel with islands and sandbars, heavy sediment loads, and high turbidity. In most years, high river flows began in March, fed by regional snowmelt and precipitation in the Great Plains, with a second and larger flood peak occurring in June, fed by snowmelt from the Rocky Mountains (Galat and others 2005). A mosaic of vegetation types occurred along the river, including riparian forests dominated by plains cottonwood (Populus deltoides), green ash (Fraxinus pennsylvanica), box elder (Acer negundo), peachleaved willow (Salix amygdaloides), and American elm (Ulmus americana) in the Great Plains, and a greater diversity of tree species on the lower portions of the river (Johnson and others 1976; Bragg and Tatschl 1977; NRC 2002).

Large-scale modifications of the river and its floodplain began with the cutting of fuel wood for steamboat travel in the early to mid-1800s, systematic removal of snags from the channel in the 1830s, and efforts to develop a $1.8 \mathrm{~m}$ navigation channel between Kansas City and St. Louis between 1891 and 1932. Further efforts to develop a "selfscouring" navigation channel on the lower Missouri culminated in the completion of a uniform, $2.7 \mathrm{~m}$ deep and $91 \mathrm{~m}$ wide channel from St. Louis to Sioux City, Iowa (1,183 river kilometers) by 1981 under the Missouri River Bank Stabilization and Navigation Project (Schneiders 1999; Galat and others 2005). Regulation of flows for flood control, hydroelectric power, and navigation began with completion of Fort Peck Dam in 1937, followed by construction of five more large dams between 1946 and 1963 (Table 1) on the upper two-thirds (Fig. 1) of the river (Schneiders 1999; Galat and others 2005).

Fluvial geomorphic processes have been greatly altered over much of the Missouri, with lowered peak flows, sharp declines in sediment transport (current loads range from 0 to $17 \%$ of historical; Jacobson and others 2009), increased low flows, and shifts in seasonal flow patterns due to dam operations (Galat and Lipkin 2000; NRC 2002, 2011). On the channelized lower river, large declines in channel area and complexity (e.g., loss of islands, sandbars, side channels and backwaters) have accompanied channelization, bank revetment, land accretion, and construction of flood 
Table 1 Data on major Missouri River mainstem reservoirs ${ }^{a}$

\begin{tabular}{|c|c|c|c|c|c|c|c|c|}
\hline Dam & Reservoir & $\begin{array}{l}\text { Dam Location in } \\
\text { km from mouth } \\
(1960)\end{array}$ & $\begin{array}{l}\text { Date } \\
\text { construction } \\
\text { started }\end{array}$ & $\begin{array}{l}\text { Date of } \\
\text { closure }\end{array}$ & $\begin{array}{l}\text { Date in } \\
\text { operation }\end{array}$ & $\begin{array}{l}\text { Reservoir } \\
\text { length in } \\
\mathrm{km}\end{array}$ & $\begin{array}{l}\text { Maximum } \\
\text { reservoir Area } \\
\text { in hectares }\end{array}$ & $\begin{array}{l}\text { Gross reservoir } \\
\text { storage in } \mathrm{m}^{3} \times 10^{6} \\
(\text { acre-ft) }\end{array}$ \\
\hline $\begin{array}{l}\text { Fort } \\
\text { Peck }\end{array}$ & $\begin{array}{l}\text { Fort Peck } \\
\text { Lake }\end{array}$ & 2851.0 & 1933 & $6 / 24 / 1937$ & 1940 & 216 & 97,529 & $22,774(18,463,000)$ \\
\hline Garrison & $\begin{array}{l}\text { Lake } \\
\text { Sakakawea }\end{array}$ & 2236.8 & 1946 & $4 / 15 / 1953$ & 1955 & 286 & 153,781 & $29,383(23,821,000)$ \\
\hline Oahe & Lake Oahe & 1725.7 & 1948 & $8 / 3 / 1958$ & 1962 & 372 & 151,352 & $28,539(23,137,000)$ \\
\hline Big Bend & Lake Sharpe & 1589.1 & 1959 & $7 / 24 / 1963$ & 1964 & 129 & 24,686 & $2,218(1,798,000)$ \\
\hline $\begin{array}{l}\text { Fort } \\
\text { Randall }\end{array}$ & $\begin{array}{l}\text { Lake Francis } \\
\text { Case }\end{array}$ & 1416.2 & 1946 & $7 / 20 / 1952$ & 1953 & 172 & 41,278 & $6,683(5,418,000)$ \\
\hline $\begin{array}{r}\text { Gavins } \\
\text { Point }\end{array}$ & $\begin{array}{l}\text { Lewis and } \\
\text { Clark Lake }\end{array}$ & 1305.3 & 1952 & $7 / 31 / 1955$ & 1955 & 40 & 12,141 & $555(450,000)$ \\
\hline TOTAL & & & & & & 1215 & 480,767 & $90,151(73,087,000)$ \\
\hline
\end{tabular}

control levees (Funk and Robinson 1974; Hallberg and others 1979; USACE 2002), along with large-scale conversion of floodplain forest to agriculture and other land uses (Bragg and Tatschl 1977; Hesse 1996). Alterations of habitat and flow and sediment regimes have been blamed for declines of river fauna, including threatened and endangered species of sandbar-nesting birds (Piping Plover, Charadrius melodus; Interior Least Tern, Sternula antillarum athalassos) and large river fishes (e.g., Pallid Sturgeon, Scaphirhynchus albus), leading to federal efforts to recover populations of these species. Changes in flow and sediment regimes have also been linked to declines in cottonwood recruitment (Johnson 1992; Scott and others 1997), leading to concerns over long-term sustainability of these forests and the need for comprehensive assessment of their extent, condition, and trajectory (USFWS 2003; Johnson and others 2012).

\section{Methods}

\section{Study Segments}

We mapped and sampled seven segments along the upper, unchannelized Missouri River, between Ponca, Nebraska (river km 1211.8) and Fort Benton, Montana (river km 3336.8 ), constituting 1,127 river $\mathrm{km}$, or roughly $53 \%$ of the entire reach (Table 2; Fig. 1). Five of the seven were selected because of their designation as moderate to high priority segments for Bald Eagle habitat (USFWS 2003). Segment numbers follow those used by the U.S. Army Corps of Engineers in the 2003 Biological Opinion (USFWS 2003; Jacobson and others 2010), except for the addition of the segment upstream from Fort Peck Lake (our segment "0"). Our study segments included two primarily reservoir segments (6 and 9) and five riverine, remnant floodplain segments $(0,2,4,8,10)$, which varied in terms of valley width, geographic position, and upstream dam operations (Tables 1, 2; Fig. 1). All segments are influenced by upstream dams, with the greatest impacts on segments below a single (segment 2) or series (segments 4 , $8,10)$ of large, upstream storage reservoirs, with less altered flows above Fort Peck (e.g., segment 0) (Galat and Lipkin 2000).

For mapping, we defined study area boundaries longitudinally by the extent of the segment and laterally by the valley wall. This lateral extent includes areas of present and historically active floodplain, including terrace deposits within the valley walls. On segment 10 , where portions of the valley are very wide $(>16 \mathrm{~km})$, we truncated the lateral boundary to the extent of our historical (1892) maps, or the valley wall, whichever was closer.

\section{Land Cover and Forest Age Class Mapping}

We obtained historical aerial photography from 2006, the 1950s (1951-58), and the 1980s (1980-87), and historical maps from the 1890s (MRC 1895) for all study segments. 2006 images (supplemented with 2008 imagery for some features in segment 10) were obtained from the USDA NRCS Geospatial Data Gateway (http://datagateway.nrcs. usda.gov/), and were color, county mosaic digital orthophotographs from the National Agricultural Imagery Project (NAIP), with a $2 \mathrm{~m}$ pixel resolution (1 $\mathrm{m}$ for 2008). Scanned imagery from the 1950s and 1980s was obtained from the USDA Aerial Photography Field Office (http:// 
Table 2 Description of study segments

\begin{tabular}{|c|c|c|c|c|c|c|}
\hline $\begin{array}{l}\text { Segment } \\
\text { number }^{\mathrm{a}}\end{array}$ & Description & $\begin{array}{l}\text { River km } \\
(1960)^{\mathrm{b}}\end{array}$ & $\begin{array}{l}\text { Type of } \\
\text { segment }\end{array}$ & $\begin{array}{l}\text { Length } \\
\mathrm{km}\end{array}$ & $\begin{array}{l}\text { Area } \\
\mathrm{km}^{2}\end{array}$ & $\begin{array}{l}\text { Mean valley } \\
\text { width } \mathrm{km}^{\mathrm{d}}\end{array}$ \\
\hline 0 & $\begin{array}{l}\text { Wild and Scenic reach, Fort Benton } \\
\text { to Fort Peck Lake }\end{array}$ & $3336.8-3085.1$ & $\begin{array}{l}\text { Remnant } \\
\text { Floodplain }\end{array}$ & 251.7 & 130.2 & 0.52 \\
\hline 2 & Fort Peck Dam to Lake Sakakawea & $2850.6-2483.7$ & $\begin{array}{l}\text { Remnant } \\
\text { Floodplain }\end{array}$ & 366.9 & 1069.1 & 2.91 \\
\hline 4 & Garrison Dam to Lake Oahe & $2237-2069.6$ & $\begin{array}{l}\text { Remnant } \\
\text { Floodplain }\end{array}$ & 167.4 & 437.6 & 2.61 \\
\hline 6 & $\begin{array}{l}\text { Oahe Dam to Big Bend Dam } \\
\text { (includes Lake Sharpe) }\end{array}$ & $1725.7-1589.1$ & Reservoir & 136.6 & 294.1 & 2.15 \\
\hline 8 & Fort Randall Dam to Springfield, SD & $1416.2-1353.5$ & $\begin{array}{l}\text { Remnant } \\
\text { Floodplain }\end{array}$ & 62.8 & 144.8 & 2.31 \\
\hline 9 & $\begin{array}{l}\text { Springfield, SD to Gavins Point Dam } \\
\text { (includes Lewis \& Clark Lake) }\end{array}$ & $1353.5-1305.3$ & Reservoir & 48.1 & 145.7 & 3.03 \\
\hline \multirow[t]{2}{*}{10} & Gavins Point Dam to Ponca, Nebraska & $1305.3-1211.8$ & $\begin{array}{l}\text { Remnant } \\
\text { Floodplain }\end{array}$ & 93.5 & 757.1 & $8.10^{\mathrm{c}}$ \\
\hline & Total & & & 1127.0 & 2978.6 & 2.64 \\
\hline
\end{tabular}

www.apfo.usda.gov/) and the USGS EROS Data Center (http://eros.usgs.gov/). 1950s images were black-and-white aerial photography flown for the USDA Commodity Stabilization Service of the FSA (Farm Service Administration) at an original scale of 1:20,000, and scanned to a pixel resolution of $0.5-0.6 \mathrm{~m}$ (some coarser images at $2.8 \mathrm{~m}$ ). 1980s images (NHAP Project, 1980-1987) were color-infrared, had an original scale of 1:60,000, and were scanned to a pixel resolution of $1.3 \mathrm{~m}$. For segments 8,9 , and 10, we also obtained color digital orthophotography for 1997 and 1998 from the U.S. Army Corps of Engineers.

For the 1892 land cover, we obtained digital, georeferenced images of the Missouri River Commission maps (MRC 1895) from the U.S. Army Corps of Engineers (Jon Kragt, USACE, Omaha District, personal communication). These maps were based on surveys of topography and hydrography from 1891 to 1893 over most of the study area, and 1889-1890 for segment 0 and the upper portion of segment 2 (above Wolf Point, MT). Original map scale was $1: 63,360$, with a scanned pixel resolution of $4.6 \mathrm{~m}$.

The 2006 orthophotography served as the base map for geo-rectification of the 1950 s and 1980s imagery. Using the geo-rectification tool in ArcGIS, we selected 5-20 control points (e.g., road intersections, corners of buildings, trees, bridges, etc.) common to both images and applied 1st or 2nd order transformations to geo-reference the historical image to the base map. We aimed for RMS (root mean square) errors of $<5 \mathrm{~m}$, preferably $2-3 \mathrm{~m}$.
We interpreted and digitized land cover from the 2006, 1950s, and 1892 imagery on each segment. For the aerial photography, digitizing was done on the screen, with the image at a scale of 1:10,000 and a minimum mapping unit of 1 ha. Because of their coarser resolution, we digitized the 1892 MRC maps at a scale of 1:24,000. We developed our own land cover classification system (Table 3) specifically for the vegetation types encountered along the Missouri River and based upon our study goals and the resolution of our imagery. Vegetation types depicted on the 1892 MRC maps were reclassified according to our system.

We also used the 1892, 1950s, 1980s, late-1990s (where available) and 2006 imagery to map approximate age classes of riparian woody vegetation in 2006, using the following steps: (1) selected polygons on the 2006 land cover that corresponded to riparian forest, woodland, or shrubland; (2) visually overlaid these polygons with imagery from 1997/1998, 1980s, 1950s, and 1892; (3) determined the interval during which the present woody vegetation colonized the polygon of interest (e.g., converted from sandbar to woody vegetation); (4) assigned the polygon, or portions of it, the age class consistent with that establishment interval (e.g., >114, 50-114, 25-50, 10-25, or $<10$ years old).

Field reconnaissance (ground-truthing) was used to refine determinations of mapped land cover, stand type and age. Ground-truthing was accomplished by sampling vegetation structure and composition within focal stands, and by visual inspection while boating or driving along each 
Table 3 Land cover categories used for GIS mapping of 2006 land cover

\begin{tabular}{|c|c|c|}
\hline $\begin{array}{l}\text { Summarized land } \\
\text { cover types }\end{array}$ & Description & Includes the following land cover types \\
\hline River & & $\begin{array}{l}\text { River channel or reservoir (open water) } \\
\text { Oxbow lake/backwater }\end{array}$ \\
\hline Sandbar & & Unvegetated sandbar \\
\hline Pond, Lake & & Farm ponds, other open water habitats \\
\hline $\begin{array}{l}\text { Forest and } \\
\text { woodland: } \\
\text { cottonwood }\end{array}$ & $\begin{array}{l}\text { Woody plants }>6 \mathrm{~m} \text { tall account for } 25-50 \% \text { (woodland) } \\
\text { or }>50 \% \text { (forest) of canopy, cottonwood } \geq 10 \% \text { of } \\
\text { canopy }\end{array}$ & $\begin{array}{l}\text { Cottonwood forest } \\
\text { Cottonwood woodland } \\
\text { Managed cottonwood forest/woodland (e.g., parks with } \\
\text { cleared understory, cabins) } \\
\text { Flooded forest (1950s for segment } 9 \text { only) }\end{array}$ \\
\hline $\begin{array}{l}\text { Forest and } \\
\text { Woodland: Non- } \\
\text { cottonwood }\end{array}$ & $\begin{array}{l}\text { Woody plants }>6 \mathrm{~m} \text { tall account for } 25-50 \% \text { (woodland) } \\
\text { or }>50 \% \text { (forest) of canopy, cottonwood }<10 \% \text { of } \\
\text { canopy }\end{array}$ & $\begin{array}{l}\text { Non-cottonwood floodplain forest } \\
\text { Non-cottonwood floodplain woodland }\end{array}$ \\
\hline $\begin{array}{l}\text { Shrubland: } \\
\text { Cottonwood }\end{array}$ & $\begin{array}{l}\text { Woody plants }<6 \mathrm{~m} \text { tall account for } 25-100 \% \text { of canopy, } \\
\text { cottonwood } \geq 10 \% \text { of canopy, }\end{array}$ & $\begin{array}{l}\text { Cottonwood shrubland } \\
\text { Riparian low shrub with cottonwood (successional sandbar } \\
\text { sites, may include mixture of low woody and herbaceous } \\
\text { vegetation }\end{array}$ \\
\hline $\begin{array}{l}\text { Shrubland: Non- } \\
\text { cottonwood }\end{array}$ & $\begin{array}{l}\text { Woody plants }<6 \mathrm{~m} \text { tall, account for } 25-100 \% \text { of } \\
\text { canopy, cottonwood }<10 \% \text { of canopy }\end{array}$ & $\begin{array}{l}\text { Non-cottonwood riparian shrubland } \\
\text { Riparian low shrub without cottonwood }\end{array}$ \\
\hline $\begin{array}{l}\text { Other woody } \\
\text { vegetation }\end{array}$ & & $\begin{array}{l}\text { Upland Forest (not in floodplain) } \\
\text { Woodlots (planted trees in farm woodlots, shelterbelts, } \\
\text { orchards) } \\
\text { Planted cottonwood trees }\end{array}$ \\
\hline Grassland & & Grassland, pasture \\
\hline Wetland & & $\begin{array}{l}\text { Emergent wetland vegetation (off river) } \\
\text { Riparian low herbaceous vegetation (successional sandbar } \\
\text { sites) }\end{array}$ \\
\hline Agriculture & & $\begin{array}{l}\text { Agricultural row crops } \\
\text { Flooded open area, mostly former cropland (1950s for } \\
\text { segment } 9 \text { only) } \\
\text { Farmstead and building complex (excluding woodlots) }\end{array}$ \\
\hline Urban & & $\begin{array}{l}\text { Town, city } \\
\text { Commercial/Industrial/Transportation (roads, parking lots, } \\
\text { boat landings) } \\
\text { Urban/recreational grasses (developed right-of-ways, golf } \\
\text { courses) }\end{array}$ \\
\hline Other & & $\begin{array}{l}\text { Barren (does not include in-channel sandbars) } \\
\text { Other, disturbed / abandoned agriculture } \\
\text { Unknown (primarily 1892, land cover not indicated on source } \\
\text { map) } \\
\text { Bluffs (1892 maps only, details on vegetation not shown) }\end{array}$ \\
\hline
\end{tabular}

segment. Ages of some stands on segments 0, 2, and 4 were verified by tree-coring. Identities of cottonwood or noncottonwood stands and observed discrepancies in land cover or forest age class were noted on field maps and subsequently revised in the GIS files. In part because our maps were updated iteratively based on ground-truthing, we did not conduct any formal analysis of classification error. Cottonwood and non-cottonwood stands were only distinguished in the 2006 mapping, as ground-truthing was necessary to reliably identify stand type. A rather low threshold of cottonwood dominance (cottonwood canopy cover $>10 \%$ ) was used for defining cottonwood stands so as to include older stands that, while dominated numerically by smaller, later successional tree species (e.g., 
Fraxinus pennsylvanica, Ulmus americana, Acer negundo, and others), still retained large cottonwoods that could provide nesting or roosting habitat for eagles.

To estimate land cover transitions and geomorphic process rates (net erosion and accretion), we overlaid features from pairs of imagery dates and computed the areas that changed from one land cover type to another (e.g., from water or sandbar to forest). These represent net changes between widely spaced dates (50-64 years) and hence underestimate the total amount of intervening erosion and deposition that may have occurred. Unvegetated sandbars and water features were considered part of the active channel and hence were treated as "aquatic" features (vs. vegetated, terrestrial features) for estimates of net erosion and deposition. Estimates of habitat areas at the land-water interface and geomorphic process rates are likely to be affected by the flows that occurred on the image dates, with less sandbar area exposed at higher flows than at lower flows. Mean daily flows were roughly similar between our 1950s and 2006 imagery dates on each segment and did not include periods of peak flows (Table 4), although stage for a given discharge may vary within and between years as channel morphology changes (R. Jacobson, pers. comm.). Flows were more variable within individual segments, however, for the 1950s, as multiple dates (including different months and years) were needed to achieve full areal coverage. For the 1890s maps, specific mapping dates and daily flow data were unavailable, but notes on the maps suggested that most segments were mapped at seasonal low flow conditions (Table 4). Higher stage values for the middle portion of segment 2 suggest that sandbar area may have been underestimated for this area, relative to other areas mapped on the 1890s imagery.

We used MS-Excel 2010 and PC-SAS ${ }^{\circledR} 9.2$ for statistical analyses, which included paired t-tests of changes in geomorphic process rates between time periods (1892-1950s vs. 1950s-2006) and differences between erosion and accretion rates within time periods, with nonreservoir segments $(n=5)$ treated as statistical replicates for all comparisons. Statistical significance was defined at $p \leq 0.05$ for all tests.

\section{Results}

\section{Historical Land Cover Change}

Anthropogenic land cover greatly increased within the Missouri River valley over the last century, converting it from a landscape dominated by forest $(28 \%)$ and grassland (33\%) in 1892, to one dominated by agricultural land (41\%) and river/reservoir (22\%) in 2006 (Figs. 2, 3, 4; Tables 6, 8 in Appendix). Agricultural land increased six- fold from 1892 to the 1950s, occupying $43 \%$ (15-70\% among segments) of the mapped area by the $1950 \mathrm{~s}$ (Fig. 2a), but (with the exception of segments 10 and 2) remained stable or decreased over 1950s-2006. Total river/ reservoir surface area increased $54 \%$ over the 1950s-2006, mostly from reservoir filling on segments 6 (Lake Sharpe) and 9 (Lewis and Clark Lake) (Figs. 2b, 4). Urban land area increased nearly seven-fold from 1892 to 2006, with a particularly large increase on segment 4 (which contains Bismarck, ND), but remained a minor component of most segments (Fig. 2c). Declines in natural land cover accompanied these increases in anthropogenic land cover, with a $49 \%$ decline in riparian forest, $52 \%$ in riparian shrubland, $61 \%$ in grassland, and $96 \%$ in unvegetated sandbar over 1892-2006 across the seven segments (Fig. 2d-g).

Most forest loss occurred between 1892 and the 1950s (Fig. 2d). Forest area declined $44 \%$ over 1892-1950s, but only $9 \%$ over 1950 s-2006. Pre-1950s forest losses were closely connected to agricultural expansion, with the net conversion of $>39 \%$ of the 1892 forest area to agriculture on segments $2,8,9$, and 10 (Table 5). Significant forest loss during the 1950s-2006 occurred primarily on reservoir segments ( $>80 \%$ loss on segments 6 and 9) (Fig. 2d) and on segment 10 , where high rates of agricultural conversion continued. Forest area increased during 1950s-2006 on the two most upstream segments (0 and 2), from woody vegetation expansion within the active channel and from maturation of shrubs that had colonized during the prior period (Table 5).

Despite having similar net declines as forest, riparian shrublands (which included young age classes of forest) showed different spatio-temporal patterns of change, with increases in some segments $(0,2,6,8)$ and decreases in others $(4,9,10)$ during 1892-1950s and steep declines on all segments during 1950s-2006 (Fig. 2e). Strongest post1950s declines occurred on the two reservoir segments. Losses on remnant floodplain segments appeared to be largely due to maturation of existing (1950s) shrubland to forest (e.g., segments 0, 2, 8) (Table 5) and to reductions in the geomorphic processes needed to create sandbar sites for shrub/sapling colonization (see below).

Grassland area declined sharply on all segments over 1892-1950s, in tandem with agricultural expansion, with declines of $>89 \%$ on segments 8,9 , and 10 (Fig. 2f). Losses continued on some segments in 1950s-2006 due to further expansion of agricultural cropland (e.g., segment 10) and to permanent inundation from reservoir filling (segments 6 and 9). Concurrent expansion of grassland and wetland (Fig. 2h) and loss of other land cover types (e.g., forest, agricultural cropland) at the downstream end of inter-reservoir segments (e.g., 2, 4, 8) appears to be related to rising water levels due to sedimentation, channel bed aggradation, and delta formation at the river-reservoir interface. 
Table 4 Dates of aerial imagery used in land cover area estimates and daily river discharge (in $\mathrm{m}^{3} / \mathrm{s}$ ) or relative stage values (for 1890 s Missouri River Commission maps) for those dates

\begin{tabular}{|c|c|c|c|c|c|c|c|c|}
\hline Seg. & $\begin{array}{l}\text { USGS } \\
\text { gage \# }\end{array}$ & Location & $\begin{array}{l}2006 \\
\text { Image } \\
\text { dates } \\
\text { (month/ } \\
\text { day) }\end{array}$ & $\begin{array}{l}2006 \text { Discharge } \\
\text { Mean } \pm \mathrm{SD} \\
(\min -\max ) \mathrm{m}^{3} / \mathrm{s}\end{array}$ & 1950s Image dates (month/day) & $\begin{array}{l}\text { 1950s } \\
\text { Discharge } \\
\text { Mean } \pm \text { SD } \\
(\min -\max ) \mathrm{m}^{3} / \mathrm{s}\end{array}$ & $\begin{array}{l}\text { 1890s } \\
\text { Image } \\
\text { dates }\end{array}$ & $\begin{array}{l}1890 \mathrm{~s} \\
\text { stage }^{\mathrm{d}}\end{array}$ \\
\hline 0 & 06090800 & $\begin{array}{l}\text { Ft. Benton, } \\
\text { MT }\end{array}$ & $\begin{array}{l}6 / 24,6 / 26 \\
7 / 16 \\
7 / 18\end{array}$ & $\begin{array}{l}165.3 \pm 22.1 \\
\quad(143.9-185.5)\end{array}$ & $\begin{array}{l}\text { 8/1, 8/7, 8/17, 9/1 (1951); 6/8, 6/9 } \\
\quad(1952)\end{array}$ & $\begin{array}{r}180.0 \pm 172.7 \\
(76.2-600.3)\end{array}$ & $\begin{array}{c}\text { May- } \\
\text { Sept. } \\
1889, \\
\text { June- } \\
\text { Oct. } \\
1890\end{array}$ & 0 \\
\hline 2 & 06132000 & $\begin{array}{l}\text { Ft. Peck, } \\
\text { MT }\end{array}$ & $\begin{array}{l}7 / 9,7 / 17 \\
8 / 19 \\
8 / 21\end{array}$ & $\begin{array}{l}230.8 \pm 4.90 \\
\quad(223.7-235.0)\end{array}$ & $\begin{array}{l}8 / 1,8 / 4-5,8 / 13,8 / 21-23,9 / 17 \\
9 / 20,9 / 25,10 / 1,10 / 3-4,11 / 26 \\
(1956) ; 6 / 23,7 / 28,9 / 14,9 / 25 \\
(1957) ; 8 / 1-2(1958)\end{array}$ & $\begin{array}{r}211.9 \pm 59.6 \\
\quad(122.1-291.7)\end{array}$ & $\begin{array}{c}\text { June- } \\
\text { Oct. } \\
1890, \\
\text { June- } \\
\text { Oct. } \\
1891\end{array}$ & $\begin{array}{l}0 \\
(28 \%) \\
6 / 10 \\
(9 \%) \\
4 / 10 \\
(19 \%) \\
2 / 10 \\
(14 \%) \\
1 / 10 \\
(31 \%)\end{array}$ \\
\hline 4 & 06342500 & $\begin{array}{l}\text { Bismarck, } \\
\text { ND }\end{array}$ & $\begin{array}{l}7 / 9,7 / 17 \\
8 / 6,8 / 21\end{array}$ & $\begin{array}{l}612.4 \pm 13.6 \\
(597.49-628.6)\end{array}$ & $\begin{array}{l}\text { 8/24, 10/1, 10/27 (1957); 5/15, } \\
\quad 7 / 24(1958)\end{array}$ & $\begin{array}{r}490.5 \pm 154.2 \\
\quad(334.1-673.9)\end{array}$ & $\begin{array}{l}\text { June- } \\
\text { Nov. } \\
1891\end{array}$ & $1 / 10$ \\
\hline $6^{\mathrm{a}}$ & 06440000 & Pierre, SD & $\begin{array}{l}7 / 11-12 \\
7 / 15 \\
7 / 28 \\
7 / 30\end{array}$ & $\begin{array}{l}876.7 \pm 42.4 \\
(826.9-943.0)\end{array}$ & $\begin{array}{l}8 / 4,8 / 9,9 / 11 \text { (1955); 7/24, 8/14 } \\
\quad(1956)\end{array}$ & $\begin{array}{r}753.8 \pm 131.5 \\
(606.0-877.8)\end{array}$ & $\begin{array}{l}\text { Sept.- } \\
\text { Nov. } \\
1892\end{array}$ & $1 / 10$ \\
\hline $8^{\mathrm{a}}$ & 06453000 & $\begin{array}{l}\text { Ft. Randall, } \\
\text { SD }\end{array}$ & $\begin{array}{l}7 / 12,7 / 15 \\
7 / 18\end{array}$ & $\begin{array}{r}698.49 \pm 20.09 \\
(676.8-716.4)\end{array}$ & $\begin{array}{l}\text { 7/22, 7/24, 9/9 (1955); 6/26, 6/28, } \\
\text { 8/5 (1956); 6/21 (1957) }\end{array}$ & $\begin{array}{l}979.8 \pm 356.3 \\
\quad(368.1-1407.4)\end{array}$ & $\begin{array}{l}\text { Sept.- } \\
\text { Nov. } \\
1892\end{array}$ & $1 / 10$ \\
\hline $9^{\mathrm{a}}$ & 06453000 & $\begin{array}{l}\text { Ft. Randall, } \\
\text { SD }\end{array}$ & $\begin{array}{l}7 / 12,7 / 15 \\
7 / 18\end{array}$ & $\begin{array}{l}698.49 \pm 20.1 \\
(676.8-716.4)\end{array}$ & $\begin{array}{l}\text { 6/26, 6/28 (1956); 6/18, 6/21 } \\
\quad(1957)\end{array}$ & $\begin{array}{l}843.3 \pm 653.6 \\
(193.1-1407.4)\end{array}$ & $\begin{array}{l}\text { Sept.- } \\
\text { Nov. } \\
1892\end{array}$ & $1 / 10$ \\
\hline $10^{\mathrm{ab}}$ & 06467500 & $\begin{array}{l}\text { Yankton, } \\
\text { SD }\end{array}$ & $\begin{array}{l}7 / 6,7 / 9 \\
7 / 15 \\
(2006) ; \\
7 / 1-3, \\
8 / 8 \\
(2008)\end{array}$ & $\begin{array}{l}537.6 \pm 203.9 \\
(283.2-722.1)\end{array}$ & $\begin{array}{l}5 / 19,5 / 30(1955) ; 6 / 9-11,6 / 24 \\
\quad(1956)\end{array}$ & $\begin{array}{l}834.4 \pm 37.6 \\
(792.9-883.5)\end{array}$ & $\begin{array}{l}\text { Sept.- } \\
\text { Nov. } \\
1892\end{array}$ & $1 / 10$ \\
\hline
\end{tabular}

\footnotetext{
a 2006 and 2008 daily discharge data for these segments was obtained from U.S. Army Corps of Engineers dam discharge data

${ }^{b}$ Represents combination of 2006 and 2008 discharge data. Most features digitized on 2006 imagery, except for constructed sandbar and constructed backwater features, which were digitized based on 2008 imagery

${ }^{c}$ Mean and standard deviation of flows on imagery dates are based on each flow date weighted evenly (that is, not weighted by number of photographs for a particular flow date)

d Based on notes on Missouri River Commission maps (MRC 1895) that depicted stage at time of mapping in terms of "tenths of the interval between standard low and standard high water." Percentage values for segment 2 indicate the percentage of the segment length for each stage value. For rest of segments, $100 \%$ of lengths are at designated stage value
}

Severe declines in the estimated areas of unvegetated sandbars occurred during both time periods, with 51 and $93 \%$ declines in 1892-1950s and 1950s-2006, respectively (Fig. 2f). Cumulative sandbar losses were strong on all segments, including both reservoir (97-99.8\%) and remnant floodplain (92-98\%) segments. On remnant floodplain segments, declines in sandbar area were accompanied by moderate (5-39\%) declines in active channel (river and sandbar) width (Fig. 5), particularly in 1950s-2006, suggesting that much of the lost sandbar area converted to terrestrial land cover. 
Fig. 2 Land cover changes within the seven study segments for percent a agricultural land cover, $\mathbf{b}$ river/reservoir surface area, c urban land cover, d riparian forest and woodland, e riparian shrubland,

f grassland, $\mathbf{g}$ unvegetated sandbar area, and $\mathbf{h}$ wetland area
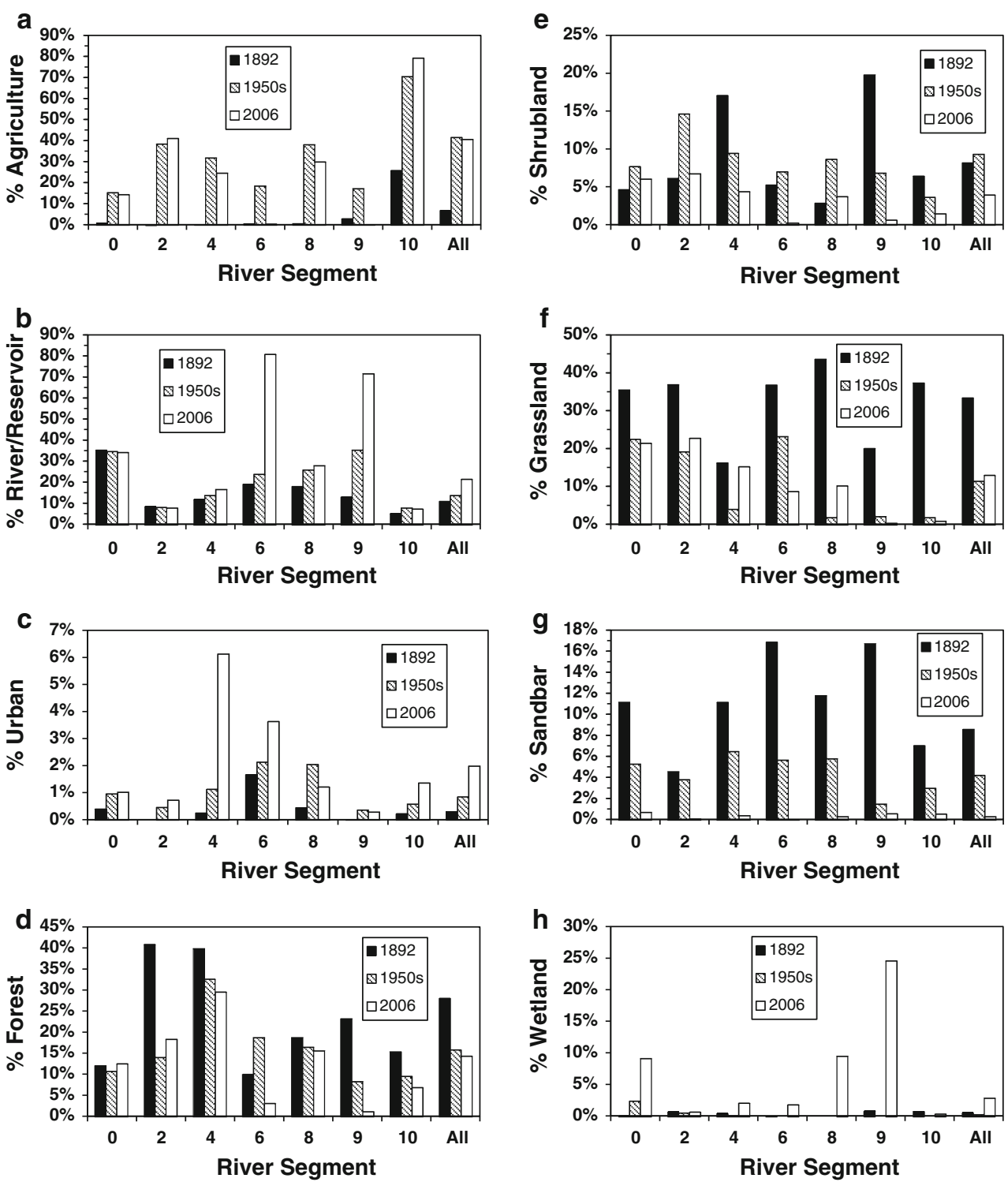

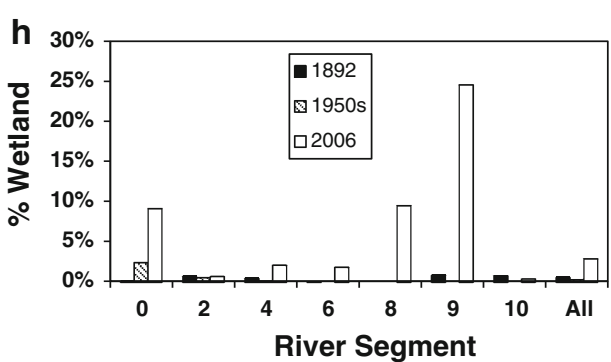

\section{Erosion and Accretion Rates}

Net geomorphic process rates declined between time periods, with stronger declines in erosion (from land to active channel) than accretion (from active channel to land) (Fig. 6). Across the five remnant floodplain segments, average net annual rates of erosion declined $67 \%$ from the $1892-1950$ s to $1950 \mathrm{~s}-2006$ time period $(0.45 \mathrm{ha} / \mathrm{km} /$ year vs. $0.15 \mathrm{ha} / \mathrm{km} /$ year; paired $t=3.19, d f=4, p=0.033)$. Declines in net accretion $(0.51 \mathrm{ha} / \mathrm{km} /$ year vs. $0.37 \mathrm{ha} / \mathrm{km} /$ year) were not significant $(p=0.065)$. Accretion rates were 2.5 -fold higher than erosion rates $(0.37 \mathrm{ha} / \mathrm{km} /$ year vs. $0.15 \mathrm{ha} / \mathrm{km} /$ year; paired $t=2.92, d f=4, p=0.043$ ) over the 1950s-2006 period and were generally, but not significantly $(p=0.19)$, greater than erosion rates over 1892-1950s. Rates of net accretion and erosion for both periods (particularly 1892-1950s) increased longitudinally from upstream to downstream, suggesting increases in geomorphic dynamism as river discharge (and often valley width) increased downstream.

Area and Age Structure of Cottonwood Stands

Across all study segments, 46,785 ha (42 ha/ $\mathrm{km})$ were classified as cottonwood forest, woodland, or shrubland in 2006, with stands in which cottonwood was a major component ( $>10 \%$ of canopy cover) representing $86 \%$ of the total woody riparian area. Highest coverage of cottonwood patch types $(39-68 \mathrm{ha} / \mathrm{km})$ occurred on four remnant floodplain segments $(2,4,8,10)$; while lowest coverage $(<8 \mathrm{ha} / \mathrm{km})$ occurred on the two reservoir segments (6 and 9) and the most upstream remnant floodplain 


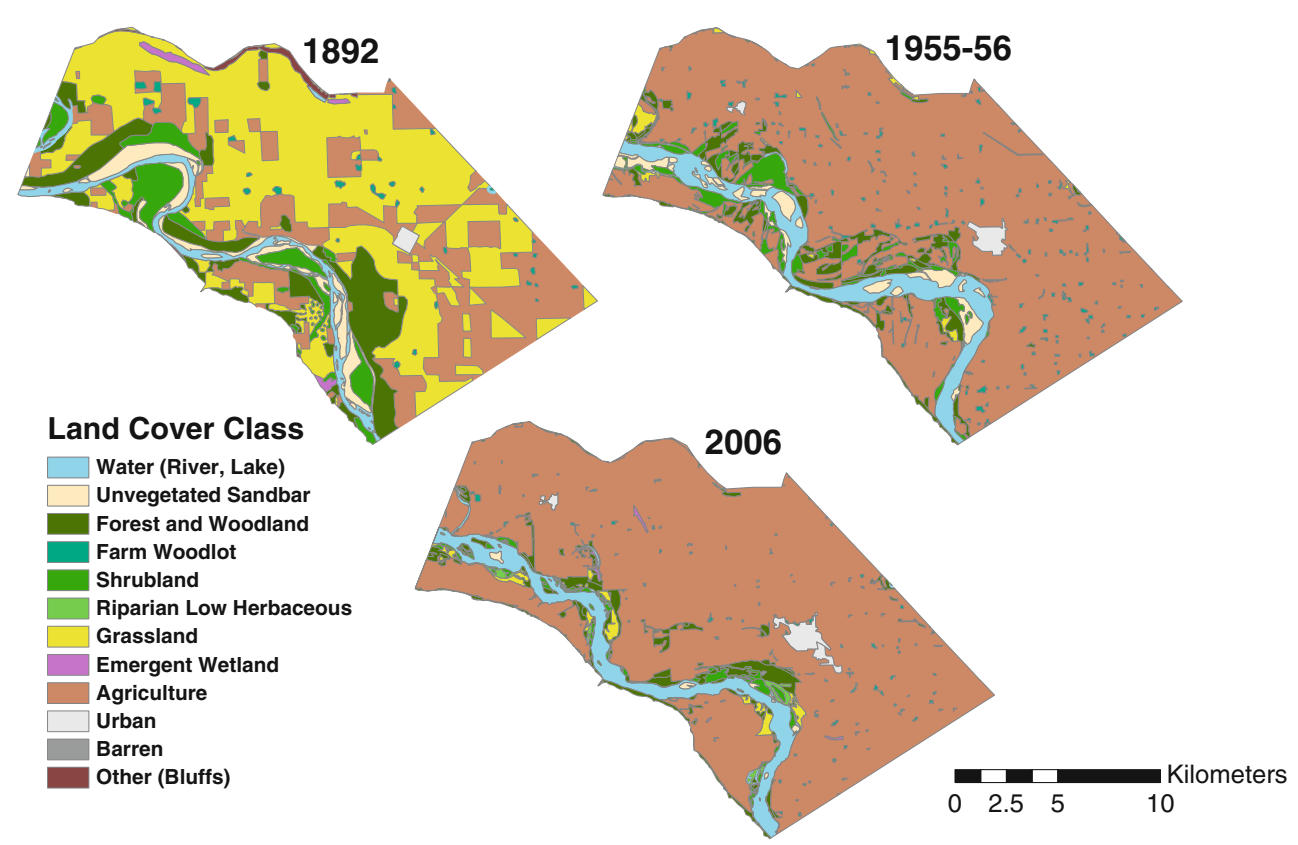

Fig. 3 Historical changes in land cover on lower one-third of segment 10

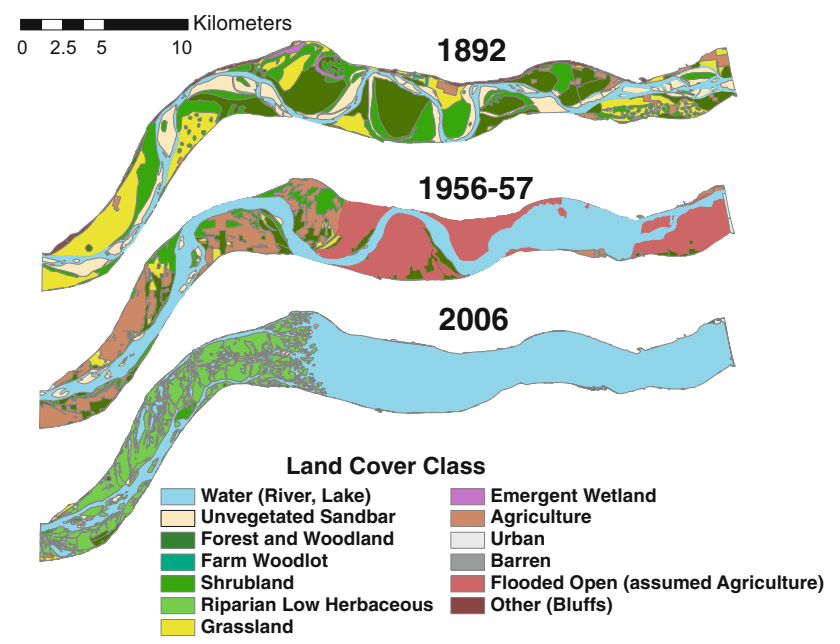

Fig. 4 Historical changes in land cover on segment 9 (Lewis and Clark Lake and delta)

segment (0) (Fig. 7a). Low cottonwood area on the reservoir segments was linked to permanent inundation of the floodplain and poor conditions for forest persistence or recruitment along the reservoir margins. On segment 0 , low cottonwood area was likely a function of persistent geologic constraints on lateral channel migration (see Scott and others in press) and narrow valley width (Table 2), with a large proportion of the valley composed of river channel (34-35\%) and a relatively small proportion (11-13\%) composed of forest across all dates (Fig. 2d, e).

Cohorts that established $>50$ years ago, prior to the closure of most of the mainstem dams, composed the bulk (67\%) of the cottonwood area (Fig. 7b). Among segments, post-1950s cohorts occupied $8.5-52 \%(0.4-30 \mathrm{ha} / \mathrm{km})$ of the cottonwood area, with greatest total area on segments 2 and $10(25-30 \mathrm{ha} / \mathrm{km})$, intermediate levels $(10-13 \mathrm{ha} / \mathrm{km})$ on segments 4 and 8 ; and lowest area on remnant floodplain segment $0(3 \mathrm{ha} / \mathrm{km})$ and the two reservoir segments ( 0.43 and $2.8 \mathrm{ha} / \mathrm{km}$ on segments 6 and 9 , respectively) (Fig. 7a, b). Across all study segments, about two-thirds of the post-1950s stand area was in the $25-50$ year age class ( $22 \%$ of total), with stands $<25$ years old occupying only $10 \%(4.4 \mathrm{ha} / \mathrm{km})$ of the total cottonwood area. Compared to other remnant floodplain segments, the relative areas of stands $<50(15 \%)$ and $<25$ years old $(6.6 \%)$ on segment 4 were anomalously low. On the reservoir segments, virtually no natural establishment of cottonwood has occurred within the last 25 years on segment 6 , with only 0.03 ha/ $\mathrm{km}$ of pole-aged (10-25 years) cottonwoods and zero hectares of saplings ( $<10$ years old). Total area of cottonwoods was also low on the unstable, deltaic area on segment 9, although much of it (41\%) was in cohorts $<25$ years old.

\section{Discussion}

Large-scale water resources infrastructure and land cover conversion have strongly modified the upper two thirds of the Missouri River and its historical floodplain. Our results suggest the following: (1) that agricultural land use conversion was the dominant driver of landscape change and forest loss along these segments of the Missouri, particularly prior to completion of most mainstem dams 
Table 5 Net gains (+) or losses (-) of forest and woodland from/to other land cover classes, as a percentage of original (at the beginning of the interval) forest area

\begin{tabular}{|c|c|c|c|c|c|c|c|c|}
\hline \multirow{2}{*}{$\begin{array}{l}\text { Net Forest Gains } \\
\text { or Losses from/to }\end{array}$} & \multirow[t]{2}{*}{ Interval } & \multicolumn{7}{|c|}{ Segments } \\
\hline & & $0(\%)$ & $2(\%)$ & $4(\%)$ & $6(\%)$ & $8(\%)$ & $9(\%)$ & $10(\%)$ \\
\hline \multirow[t]{2}{*}{ Agriculture } & 1892-1950s & -12.58 & -40.09 & -26.21 & -8.38 & -39.86 & -44.60 & -43.01 \\
\hline & 1950s-2006 & -0.21 & -7.31 & -4.43 & 2.32 & -4.81 & 2.87 & -47.68 \\
\hline \multirow[t]{2}{*}{ Urban } & $1892-1950 \mathrm{~s}$ & -0.18 & -0.90 & -1.16 & 0.92 & -0.37 & -0.42 & -0.06 \\
\hline & $1950 s-2006$ & 0.01 & -0.33 & -4.99 & -1.57 & 0.15 & -0.04 & -0.94 \\
\hline \multirow[t]{2}{*}{ Water/Sandbar } & $1892-1950 \mathrm{~s}$ & 7.41 & -2.76 & 15.67 & 42.48 & 7.58 & -19.03 & 3.62 \\
\hline & 1950s-2006 & 7.14 & 7.46 & 3.29 & -80.31 & -2.52 & -53.94 & 13.77 \\
\hline \multirow[t]{2}{*}{ Shrubland } & $1892-1950 \mathrm{~s}$ & 1.42 & -13.52 & 5.90 & 16.05 & -5.84 & 8.21 & 3.38 \\
\hline & 1950s-2006 & 22.49 & 31.82 & 10.78 & 1.08 & 15.55 & 0.20 & 8.64 \\
\hline \multirow[t]{2}{*}{ Wetland } & $1892-1950 \mathrm{~s}$ & -2.29 & -0.33 & -0.23 & -0.24 & -0.05 & 0.002 & 0.09 \\
\hline & 1950s-2006 & -2.78 & -0.35 & -0.52 & -3.52 & -6.49 & -37.12 & 0.25 \\
\hline \multirow[t]{2}{*}{ Grassland } & $1892-1950 \mathrm{~s}$ & -4.39 & -8.89 & 3.15 & 29.01 & 22.00 & 1.83 & 3.78 \\
\hline & 1950s-2006 & -2.02 & -0.74 & -10.53 & 0.29 & -7.55 & -0.08 & -0.45 \\
\hline \multirow[t]{2}{*}{ Other } & $1892-1950 \mathrm{~s}$ & 0.02 & -0.04 & 2.80 & 11.36 & 4.30 & 1.54 & -1.51 \\
\hline & 1950s-2006 & -1.00 & 0.66 & 0.19 & -0.18 & 0.96 & -0.68 & 0.31 \\
\hline \multirow[t]{2}{*}{ Overall } & $1892-1950 \mathrm{~s}$ & -10.58 & -65.70 & -18.21 & 91.21 & -12.24 & -52.47 & -33.70 \\
\hline & 1950s-2006 & 23.64 & 31.20 & -9.24 & -81.88 & -4.70 & -88.79 & -26.10 \\
\hline
\end{tabular}

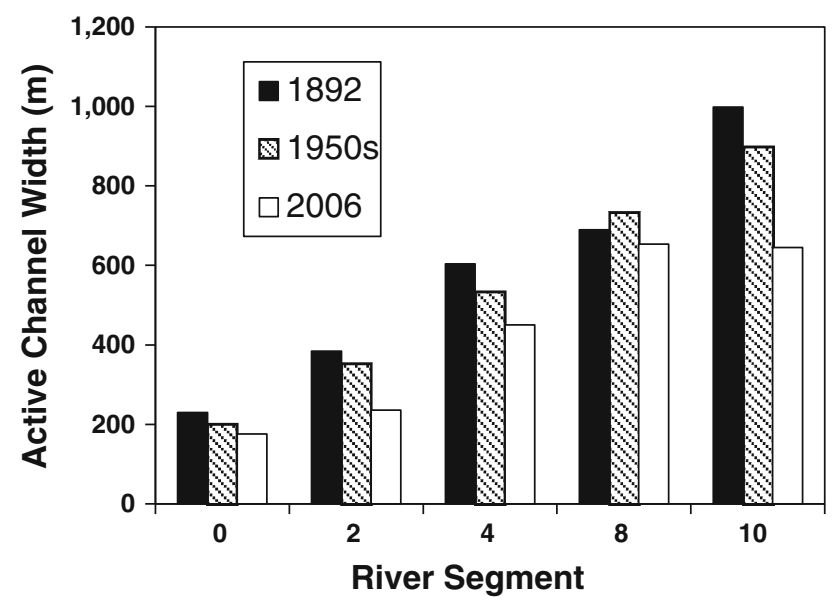

Fig. 5 Segment averaged active channel width by segment and date. Active channel width was estimated by dividing active channel area (area of unvegetated sandbars and surface water) by the length of the river segment. Reservoir segments (i.e., segments 6 and 9) are not included

(1892-1950s); (2) that reservoirs have been important drivers of landscape change in both direct and indirect ways, even on unimpounded remnant floodplain reaches; and (3) that river channel and cottonwood forest dynamics have been influenced by changes in fluvial processes from upstream dams, with cottonwood recruitment accompanying active channel narrowing during the 2-3 decades after dam closure, followed by chronic recruitment limitation due to declines in formation of alluvial surfaces.

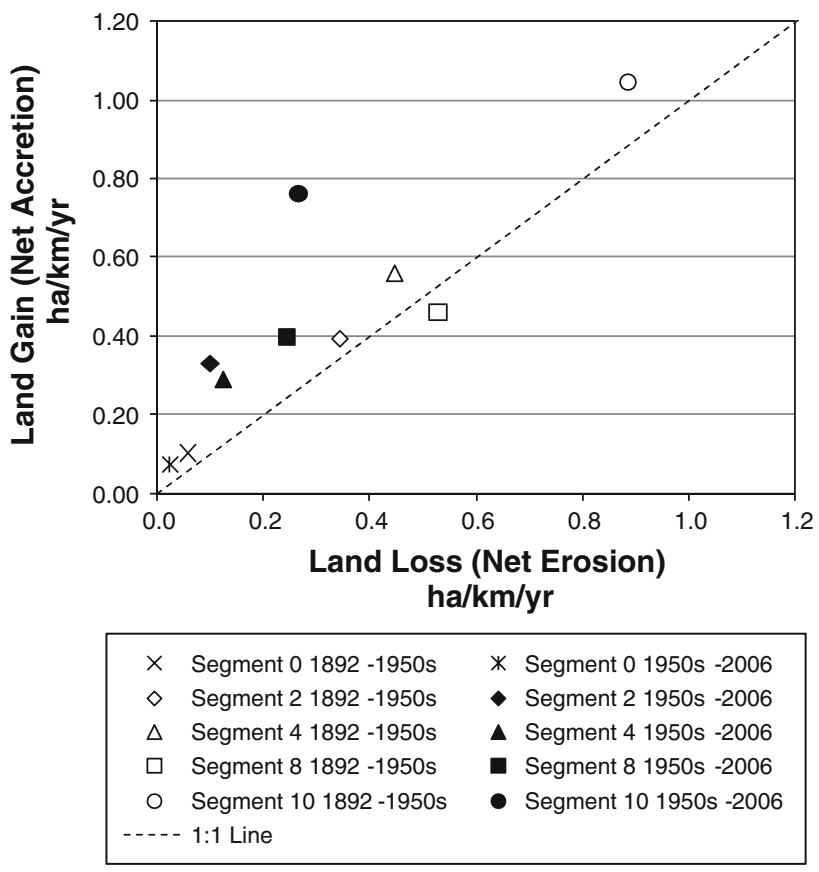

Fig. 6 Rates (ha/km/year) of land gain (net accretion) and land loss (net erosion) by periods (1892-1950s and 1950s-2006) and study segments. Reservoir segments (i.e., segments 6 and 9) are not included

\section{Effects of Land Use Change}

Conversion to agricultural cropland was the primary driver of landscape change and loss of forest and grassland land 

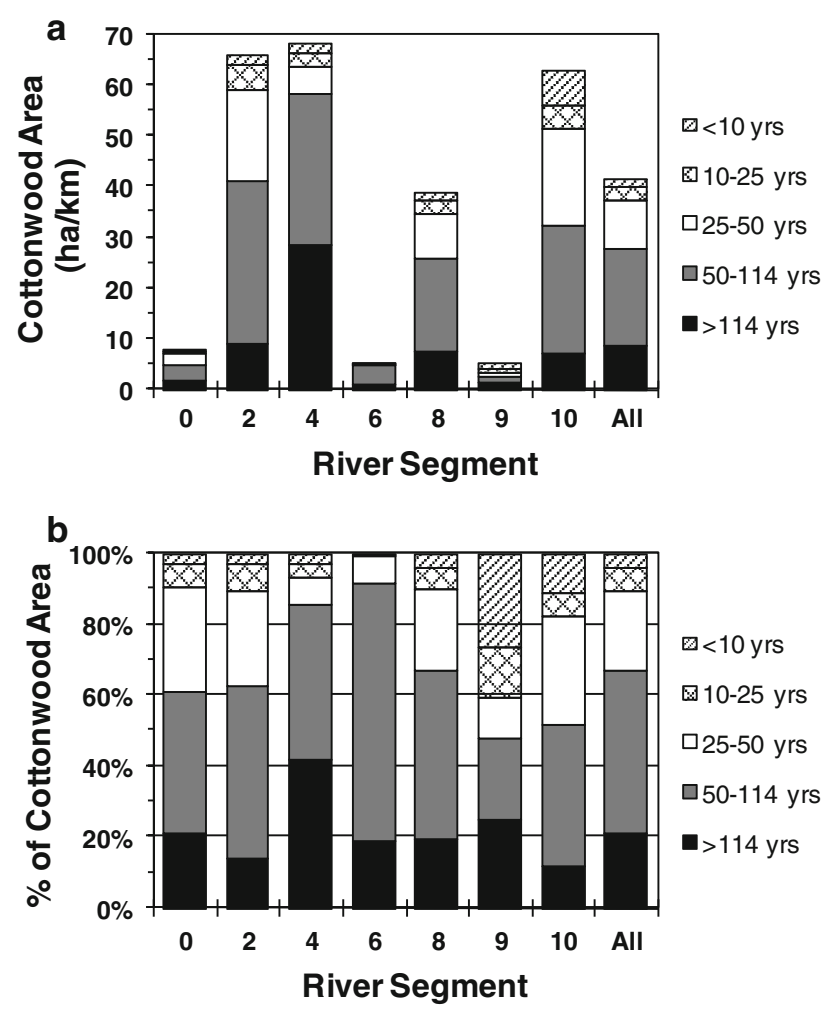

Fig. 7 Absolute (a) and relative (b) areas of different age classes of cottonwood stands, by river segment. Absolute areas are standardized by dividing by river segment length

cover within study segments. Prior studies on the channelized, lower Missouri (Funk and Robinson 1974; Bragg and Tatschl 1977; Hesse 1996) documented dramatic historical expansion of agriculture, with declines in forest and other natural land cover. Our results show that agricultural conversion has been a primary driver of landscape change and forest loss on the unchannelized, upstream segments of the Missouri as well, although the greatest impacts occurred prior to completion of most mainstem dams in the 1950s. Cropland area has remained relatively stable since the 1950s, with the exception of our most downstream segment (10), where agricultural conversion has remained an important driver of forest loss.

Although urban land cover has expanded dramatically over time, it remains a relatively minor component of the landscape and a minor direct cause of forest loss on most segments (with the exception of segment 4). Perhaps underestimated are the effects of exurban development (e.g., riverside cabins and trailers, campgrounds, low density housing), which fragment the forest and alter the understory, but may leave much of the forest canopy intact, making its impacts difficult to quantify from aerial imagery. Exurban developments may increase demand for local bank stabilization with rip-rap, restricting erosion in affected reaches, but potentially increasing it downstream.
Elliott and Jacobson (2006) indicated that $12.5 \%$ of banks on segment 8 and $32 \%$ of segment 10 were stabilized by 2006, while Angradi and others (2004) noted that $52 \%$ of banks in urban portions and $21 \%$ on rural portions of segment 4 had been stabilized by 2004. Cumulative effects of ongoing and future urban/exurban expansion and bank stabilization should be carefully considered when planning for conservation or restoration of the riparian corridor (Florsheim and others 2008).

Inundation by Reservoirs

Across the upper Missouri, permanent inundation by reservoirs has led to the loss of large areas of floodplain habitat. In our study, near complete loss of riparian forests and other floodplain habitats occurred on our two reservoir segments. Reservoirs and transitional reaches occupy approximately 1,183 river $\mathrm{km}$, or $56 \%$ of the unchannelized river between Ponca, Nebraska and Fort Benton, Montana, with a potential surface area of over 480,000 ha. Hesse (1996) estimated that the filling of Oahe Reservoir alone led to the loss of 123,000 ha of floodplain lands. If the area of floodplain per river $\mathrm{km}$ and proportional losses of forest on the other four mainstem reservoirs (Fort Peck, Sakakawea, Oahe, Fort Randall) are similar to those on segments 6 (Lake Sharpe) and 9 (Lewis and Clark Lake), then 33,500 ha or more of floodplain forest present in 1892 may have been lost on the segments containing the six large mainstem reservoirs. Not all of this loss would have been directly due to reservoir filling, however, as much of the forest present in 1892 would likely have been converted to agricultural land first, prior to reservoir filling in the 1930s-1960s.

\section{Upstream Effects of Reservoirs}

While the direct effects of reservoir inundation are well recognized, upstream effects of reservoirs on remnant floodplain segments may be an important but heretofore under-appreciated influence on forest loss and landscape change (Johnson and others 2012). Deltas have formed at the river-reservoir interface of the mainstem reservoirs, as sediments carried by the Missouri or tributaries are deposited in the slackwaters of the upper end of the reservoir and the adjacent river-reservoir transitional reach (Johnson 2002; Galat and others 2005; Coker and others 2009). This process is particularly notable downstream of where the Niobrara River, historically one of the largest providers of sediment to the upper Missouri, enters the Missouri just upstream of Lewis and Clark Lake (segments 8 and 9) (see Elliott and Jacobson 2006). Sediment inputs from the Niobrara have contributed to formation of an extensive and growing delta (Fig. 4) that has already 
reduced the storage capacity of the reservoir by over $20 \%$ in the last 55 years (Coker and others 2009). Rising groundwater and surface water levels linked to bed aggradation (USACE 2004) have converted cottonwood forest, cropland, and other land cover in the adjacent floodplain to emergent marsh, wet shrubland, and wet grassland; forced the relocation of the town of Niobrara, Nebraska in 1977 (Schneiders 1999); and currently threaten an existing state highway and other infrastructure (Coker and others 2009). Similar processes are occurring on other river-reservoir transitional areas (Johnson 2002), including between the Bad River confluence and Lake Sharpe near Pierre, SD (segment 6), between Bismarck, ND and the upper end of Lake Oahe (segment 4), and between the Yellowstone River confluence and the upper end of Lake Sakakawea near Williston, ND (segment 2) (USACE 1990, 1999, 2004; NRC 2002).

As noted by Johnson (2002), reservoir deltas are novel habitats resulting from the spatial patterning of tributaries and reservoir infrastructure. While these areas are dynamic and provide wetland and shallow water habitat, initial assessments suggest that they are low in plant diversity and are too wet to support significant areas of successful, longterm cottonwood establishment. During multi-year periods of drought, delta areas and the shallow, upstream portions and margins of reservoirs that become exposed from declining reservoir levels (e.g., up to $70 \mathrm{~km}$ on upper end of Lake Oahe) may become suitable for recruitment of cottonwood and other woody riparian species. These areas are lost, however, during subsequent wetter periods when reservoirs can be filled to their full operating capacity (Johnson 2002).

\section{Downstream Effects of Reservoirs}

Approximately $44 \%$ (942 river $\mathrm{km}$ ) of the Missouri River in our study area is in remnant floodplain segments that are between or downstream from reservoirs. These segments retain a riverine planform, relict patches of native vegetation, and other natural channel and floodplain features. Flow regimes, however, have been strongly modified by adjacent upstream reservoirs, the cumulative effects of upstream storage, and scheduling of flow releases for hydropower production and downstream navigation. Below Gavins Point Dam (segment 10), annual peak flows have been strongly reduced, seasonal patterns of high and low flows have been shifted, and flows in the historically lowflow seasons of fall and winter have increased, with similar changes noted on other segments (Galat and Lipkin 2000). Flows have been much less altered on segment 0 , the most upstream segment in our study area, and considered a "lightly-regulated" remnant floodplain reach by Johnson (2002). This segment occurs downstream of smaller, mostly run-of-the-river dams on the mainstem Missouri (Canyon Ferry Dam) and on the Marias River (Tiber Dam), a major tributary. Flows on this segment still include a spring flood pulse, albeit reduced in magnitude by $40 \%$ (Galat and Lipkin 2000; Bovee and Scott 2002).

Except where major tributaries contribute flow and sediment, reaches below large dams usually experience significant declines in sediment transport and reduced high flows, reflected in lower rates of lateral channel migration (Johnson 1992; Shields and others 2000), declines in sandbar formation, and degradation of the channel bed (Williams and Wolman 1984; Kondolf 1997; Schmidt and Wilcock 2008), with effects that can extend many $\mathrm{km}$ downstream. On the Missouri, degradation of 1.7-3.5 $\mathrm{m}$ has occurred directly below the dams on the upper ends of segments 2,4 , 8, and 10 (Shields and others 2000; USACE 2000, 2004; Jacobson and others 2009, 2011). Bed degradation reduces the probability of overbank flooding and lowers alluvial water tables, leading to increased "terrestrialization" of the historical floodplain and its vegetation. Hence, opposing processes and patterns occur on the upstream and downstream ends of inter-reservoir segments, with channel degradation leading to more xeric conditions in the floodplain below the upstream dam, while channel aggradation leads to more hydric conditions at the downstream end of the reach, above the adjacent downstream reservoir.

\section{Cottonwood Forest Extent and Dynamics}

Historical loss of floodplain forests and shrublands, as well as grasslands and other natural land cover, has been substantial along the unchannelized upper two thirds of the Missouri, with most remaining habitats occurring on remnant floodplain segments. Across the entire $2125 \mathrm{~km}$ of river between Fort Benton, MT and Ponca, NE, we estimate that the area of riparian forest and shrubland declined $70 \%$ from 1892 to 2006, based on proportional losses on our mapped segments and the total length of unmapped reservoir segments (i.e., Fort Peck, Oahe, Sakakawea, Francis Case). This may underestimate total losses, as the reservoir segments that we sampled are the smallest of the six mainstem reservoirs and hence have a larger proportional area of transitional habitat between the upstream remnant floodplain segment and the reservoir. Of the remaining shrubland and forest habitat today, we estimate that $85 \%$ occurs on the remnant floodplain segments.

As expected from the well-documented negative effects of dams on cottonwood recruitment on other meandering rivers in the region (Bradley and Smith 1986; Rood and Mahoney 1990; Johnson 1992), most stands in our study area established before most of the mainstem dams were completed. This dominance of pre-dam stands notwithstanding, significant recruitment accompanied channel narrowing in 
the 2-3 decades after completion of upstream dams, as observed on braided, sand-bed rivers in the region (Johnson 1994, 1998; Friedman and others 1998). Dam-induced reductions in peak flows may have favored persistence of recently established seedlings and saplings on sandbars by reducing mortality from ice scour or sediment mobilization (Williams and Wolman 1984; Dixon and Turner 2006; Scott and others in press). Channel degradation may have contributed to narrowing by exposing former shallow areas of the active channel, making them available for vegetation colonization (Cooper and others 2003). Available surfaces for recruitment may have also been abundant in the aftermath of the flood of April 1952, which was the flood of record on many gages and occurred just prior to closure of several dams on the upper Missouri. Steep declines in shrublands and sandbars since the 1950s and the small area of stands $<25$ years old suggest that this period of recruitment was a transient phenomenon that accompanied initial geomorphic adjustments to the post-dam flow and sediment regimes (Scott and others 1996). Recruitment over the last 25-30 years appears limited by low rates of geomorphic dynamism, low sediment supply, and a paucity of unvegetated sandbars.

Post-dam narrowing and accompanying recruitment of riparian forest partially compensated for forest losses due to conversion to agriculture, particularly on segments 0 and 2 , where (in contrast to downstream segments) the area of forest increased from the 1950s-2006. With completion of Fort Peck Dam in 1937, the period of post-dam narrowing and cottonwood recruitment on segment 2 likely began earlier than on other segments, as a large proportion of the forest gain by 2006 was from maturation of riparian shrublands already present in the 1950s. Downstream effects of Fort Peck Dam on flow and sediment regimes may have also influenced pre-1950s narrowing and vegetation colonization on other segments, including the steep expansion of forest area on segment 6.

\section{Management Implications}

Within the current regulated flow regime, process-based restoration and/or an aggressive program of planting may be necessary to address problems of chronic limitations to cottonwood recruitment along the upper two thirds of the Missouri River. Process-based restoration efforts would need to take into account restoration of natural flow patterns (Poff and others 1997), but also the need for sediment replenishment (NRC 2011), and the current difficulties posed by incised channels (Jacobson and others 2011). Even if rates of natural recruitment could be increased, such recruitment would be limited, for the most part, to the immediate banks, islands, and bars of a relatively stabilized Missouri River. Without active lateral migration or avulsion of the channel, cottonwood forest area will shrink in the future, as stands on the distal portions of the floodplain are replaced by more shade-tolerant species or are lost to land use conversion, while new recruitment is limited and confined primarily to the channel margins (e.g., Cordes and others 1997; Dixon and others 2009). These conditions differ somewhat on portions of the lower channelized river, where higher water tables and episodic reconnection of the agricultural floodplain to the river by large floods may enable recruitment on abandoned agricultural lands or restored side channel sites (Thogmartin and others 2009; Jacobson and others 2011). In general, innovative and large-scale approaches will be needed if regeneration processes sufficient to sustain the area of existing cottonwood forests are to be restored.

In the absence of significant changes in flow and sediment management, planting may be used to partially compensate for limitations in cottonwood recruitment. Such planting, however, would need to be done continually and on a large scale in order to offset future losses to natural senescence and succession or to maintain cottonwood forests over a wide expanse of historical floodplain. If most pre-dam ( $>50$ years old) cottonwood stands are lost in the next 50 years, due to mortality or other factors, and natural recruitment rates are comparable to those of the last 25 years, then at least 435 ha of new plantings per year would be needed to replace the annual losses of cottonwood area across the seven study segments. Given that plantings would occur on sites that are now largely disconnected from river processes, planted stands may differ in structure and function from those that established naturally under the pre-regulation river regime.

While restoration of recruitment processes is critical, the value of protecting remnant stands of cottonwood in the floodplain and sites where natural recruitment has or is still occurring should not be minimized. Remnant stands provide valuable habitat for forest songbirds and other wildlife, as well as aesthetic and recreational values, and may be difficult to replicate via planting (but see Golet and others 2008). Stands recruiting within the novel flow and sediment regimes of the regulated river environment provide potential for sustaining natural successional processes, albeit limited in area, on the river fringe or in the active channel. Both types of stands, particularly older remnant stands, are under threat from land conversions to agricultural and urban land use, as well as rising water tables adjacent to reservoir deltas. In addition, recruitment of young cottonwoods on channel bars may conflict with current efforts by the U.S. Army Corps of Engineers to manage sandbars as nesting habitat for the endangered Least Tern and Piping Plover (USFWS 2003, 2011; NRC 2011).

Finally, greater attention should be placed on the potential of novel riverine ecosystems, such as deltas, for sustaining cottonwood regeneration. Currently, most reservoir deltas 
and reservoir margins are unsuitable locations for recruitment and long-term persistence of cottonwoods because of stable or rising reservoir levels, chronic flooding, and perpetually saturated soils. As reservoir deltas age and aggrade, however, they may become more suitable. Some tributary deltas (i.e., where a tributary directly enters a reservoir), such as where the White River enters Lake Francis Case near Chamberlain, SD, do appear to sustain natural recruitment processes (Johnson 2002). In addition, the potential role of abandoned channels as sites of cottonwood recruitment should be recognized (Stella and others 2011). All in all, innovative approaches that recognize the valuable legacy of remnant cottonwood stands and seek to restore natural processes within the regulated river are needed to assure that cottonwood forests remain an important and dynamic component of the Missouri River floodplain in the future.

Acknowledgments Funding was provided via contract \# W912DQ07-C-0011 from the U.S. Army Corps of Engineers, Kansas City District, with additional funding from the University of South Dakota. Caleb Caton, Rebekah Jessen, Adam Benson, Lisa Yager and other students at the University of South Dakota, and Elizabeth Reynolds, Dale Kohlmetz, Christopher Peltz, Michael Dodrill, Lindsey Washkoviak, Brittany Hummel, Keir Morse, and Tara Kline from the U.S. Geological Survey assisted with field sampling and mapping. Wes Christensen, Jesse Wolff, Heather Campbell and Drew Price from USD and Tammy Fancher and Hanna Moyer from USGS conducted much of the photo-interpretation and GIS work. Jon Kragt, USACE, Omaha District, provided georeferenced, digital copies of the 1892 Missouri River Commission maps. Tim Cowman, Missouri River Institute at USD, provided historical imagery and access to computer server space. Danielle Quist provided data on historical flows on imagery dates. Malia Volke of SDSU drafted our study area map. We thank representatives from numerous agencies and institutions, including the National Park Service, U.S. Fish and Wildlife Service, U.S. Army Corps of Engineers, Bureau of Land Management, Northern Prairies Land Trust, Yankton Sioux and Lower Brule Sioux Tribes, and South Dakota Department of Game, Fish, and Parks, for providing access to field sites. Finally, we thank the numerous private landowners who graciously provided access to their land.

\section{Appendix}

See Tables 6, 7 and 8.

Table 6 Land cover (area and \% of total) from 1892 Missouri River Commission maps

\begin{tabular}{|c|c|c|c|c|c|c|c|c|}
\hline \multirow[t]{2}{*}{ Land cover } & \multicolumn{8}{|c|}{ Area (ha) by segment } \\
\hline & 0 & 2 & 4 & 6 & 8 & 9 & 10 & Total \\
\hline \multirow[t]{2}{*}{ Forest and Woodland ${ }^{\mathrm{a}}$} & 1,501 & 43,727 & 17,385 & 2,931 & 2,709 & 3,377 & 11,605 & 83,235 \\
\hline & $12.1 \%$ & $40.7 \%$ & $39.7 \%$ & $10.0 \%$ & $18.7 \%$ & $23.2 \%$ & $15.3 \%$ & $27.9 \%$ \\
\hline \multirow[t]{2}{*}{ Shrubland $^{\mathrm{a}}$} & 581 & 6,591 & 7,440 & 1,539 & 416 & 2,877 & 4,855 & 24,299 \\
\hline & $4.7 \%$ & $6.1 \%$ & $17.0 \%$ & $5.2 \%$ & $2.9 \%$ & $19.7 \%$ & $6.4 \%$ & $8.2 \%$ \\
\hline \multirow[t]{2}{*}{ Grassland } & 4,416 & 39,579 & 7,123 & 10,805 & 6,298 & 2,917 & 28,230 & 99,368 \\
\hline & $35.5 \%$ & $36.8 \%$ & $16.3 \%$ & $36.7 \%$ & $43.5 \%$ & $20.0 \%$ & $37.3 \%$ & $33.4 \%$ \\
\hline \multirow[t]{2}{*}{ River } & 4,392 & 9,197 & 5,245 & 5,639 & 2,625 & 1,920 & 4,019 & 33,037 \\
\hline & $35.3 \%$ & $8.6 \%$ & $12.0 \%$ & $19.2 \%$ & $18.1 \%$ & $13.2 \%$ & $5.3 \%$ & $11.1 \%$ \\
\hline \multirow[t]{2}{*}{ Sandbar } & 1,387 & 4,919 & 4,868 & 4,948 & 1,703 & 2,428 & 5,316 & 25,569 \\
\hline & $11.1 \%$ & $4.6 \%$ & $11.1 \%$ & $16.8 \%$ & $11.8 \%$ & $16.7 \%$ & $7.0 \%$ & $8.6 \%$ \\
\hline \multirow[t]{2}{*}{ Wetland } & 12 & 731 & 186 & 6 & 0 & 122 & 587 & 1,644 \\
\hline & $0.1 \%$ & $0.7 \%$ & $0.4 \%$ & $<0.1 \%$ & $0 \%$ & $0.8 \%$ & $0.8 \%$ & $0.6 \%$ \\
\hline \multirow[t]{2}{*}{ Pond, Lake } & 1 & 124 & 181 & 0 & 0 & 1 & 44 & 351 \\
\hline & $<0.1 \%$ & $0.1 \%$ & $0.4 \%$ & $0 \%$ & $0 \%$ & $<0.1 \%$ & $0.1 \%$ & $0.1 \%$ \\
\hline \multirow[t]{2}{*}{ Agriculture } & 109 & 10 & 84 & 156 & 100 & 431 & 19,540 & 20,430 \\
\hline & $0.9 \%$ & $<0.1 \%$ & $0.2 \%$ & $0.5 \%$ & $0.7 \%$ & $3.0 \%$ & $25.8 \%$ & $6.9 \%$ \\
\hline \multirow[t]{2}{*}{ Woodlot } & 0 & 0 & 0 & 0 & 0 & 29 & 824 & 853 \\
\hline & $0 \%$ & $0 \%$ & $0 \%$ & $0 \%$ & $0 \%$ & $0.2 \%$ & $1.1 \%$ & $0.3 \%$ \\
\hline \multirow[t]{2}{*}{ Urban } & 50 & 0 & 110 & 489 & 66 & 1 & 171 & 887 \\
\hline & $0.4 \%$ & $0 \%$ & $0.3 \%$ & $1.7 \%$ & $0.5 \%$ & $<0.1 \%$ & $0.2 \%$ & $0.3 \%$ \\
\hline \multirow[t]{2}{*}{ Bluffs } & $<1$ & 2,555 & 1,138 & 2,897 & 557 & 467 & 435 & 8,049 \\
\hline & $<0.1 \%$ & $2.4 \%$ & $2.6 \%$ & $9.9 \%$ & $3.9 \%$ & $3.2 \%$ & $0.6 \%$ & $2.7 \%$ \\
\hline \multirow[t]{2}{*}{ Other } & 0 & 0 & 0 & 0 & 0 & 0 & 70 & 70 \\
\hline & $0 \%$ & $0 \%$ & $0 \%$ & $0 \%$ & $0 \%$ & $0 \%$ & $0.1 \%$ & $<0.1 \%$ \\
\hline Total & 12,448 & 107,434 & 43,761 & 29,409 & 14,475 & 14,571 & 75,714 & 297,812 \\
\hline
\end{tabular}

${ }^{\text {a }}$ Cottonwood and non-cottonwood types not differentiated 
Table 7 Land cover (area and \% of total) from 1950s aerial imagery

\begin{tabular}{|c|c|c|c|c|c|c|c|c|}
\hline \multirow[t]{2}{*}{ Land cover } & \multicolumn{8}{|c|}{ Area (ha) by segment } \\
\hline & 0 & 2 & 4 & 6 & 8 & 9 & 10 & Total $(0-10)$ \\
\hline \multirow[t]{2}{*}{ Forest and Woodland ${ }^{\mathrm{a}}$} & 1,392 & 14,924 & 14,220 & 5,510 & 2,378 & 1,206 & 7,230 & 46,860 \\
\hline & $10.7 \%$ & $14.0 \%$ & $32.5 \%$ & $18.7 \%$ & $16.4 \%$ & $8.3 \%$ & $9.5 \%$ & $15.7 \%$ \\
\hline \multirow[t]{2}{*}{ Inund Forest ${ }^{\mathrm{ab}}$} & 0 & 0 & 0 & 0 & 0 & 399 & 0 & 399 \\
\hline & $0 \%$ & $0 \%$ & $0 \%$ & $0 \%$ & $0 \%$ & $2.7 \%$ & $0 \%$ & $0.1 \%$ \\
\hline \multirow[t]{2}{*}{ Shrubland $^{\mathrm{a}}$} & 999 & 15,539 & 4,122 & 2,057 & 1,250 & 998 & 2,773 & 27,738 \\
\hline & $7.7 \%$ & $14.6 \%$ & $9.4 \%$ & $7.0 \%$ & $8.6 \%$ & $6.8 \%$ & $3.7 \%$ & $9.3 \%$ \\
\hline \multirow[t]{2}{*}{ Grassland } & 2,923 & 20,446 & 1,798 & 6,829 & 278 & 320 & 1,498 & 34,092 \\
\hline & $22.5 \%$ & $19.2 \%$ & $4.1 \%$ & $23.2 \%$ & $1.9 \%$ & $2.2 \%$ & $2.0 \%$ & $11.5 \%$ \\
\hline \multirow[t]{2}{*}{ River } & 4,519 & 8,870 & 6,108 & 7,042 & 3,758 & 5,153 & 6,112 & 41,562 \\
\hline & $34.7 \%$ & $8.3 \%$ & $14.0 \%$ & $23.9 \%$ & $26.0 \%$ & $35.4 \%$ & $8.1 \%$ & $14.0 \%$ \\
\hline \multirow[t]{2}{*}{ Sandbar } & 690 & 4,052 & 2,826 & 1,671 & 839 & 220 & 2,281 & 12,578 \\
\hline & $5.3 \%$ & $3.8 \%$ & $6.5 \%$ & $15.7 \%$ & $5.8 \%$ & $1.5 \%$ & $3.0 \%$ & $4.2 \%$ \\
\hline \multirow[t]{2}{*}{ Wetland } & 316 & 575 & 51 & 0 & 0 & 0 & 0 & 942 \\
\hline & $2.4 \%$ & $0.5 \%$ & $0.1 \%$ & $0 \%$ & $0 \%$ & $0 \%$ & $0 \%$ & $0.3 \%$ \\
\hline \multirow[t]{2}{*}{ Pond, lake } & 57 & 622 & 139 & 131 & 11 & 6 & 193 & 1,160 \\
\hline & $0.4 \%$ & $0.6 \%$ & $0.3 \%$ & $0.4 \%$ & $0.1 \%$ & $<0.1 \%$ & $0.3 \%$ & $0.4 \%$ \\
\hline \multirow[t]{2}{*}{ Agriculture } & 1,999 & 40,811 & 13,898 & 5,437 & 5,503 & 2,511 & 53,211 & 123,370 \\
\hline & $15.4 \%$ & $38.3 \%$ & $31.8 \%$ & $18.5 \%$ & $38.0 \%$ & $17.2 \%$ & $70.3 \%$ & $41.5 \%$ \\
\hline \multirow[t]{2}{*}{ Inund open ${ }^{c}$} & 0 & 0 & 0 & 0 & 0 & 3,675 & 0 & 3,675 \\
\hline & $0 \%$ & $0 \%$ & $0 \%$ & $0 \%$ & $0 \%$ & $25.2 \%$ & $0 \%$ & $1.2 \%$ \\
\hline \multirow[t]{2}{*}{ Woodlot } & 0 & 305 & 103 & 14 & 162 & 30 & 1,506 & 2,120 \\
\hline & $0 \%$ & $0.3 \%$ & $0.2 \%$ & $<0.1 \%$ & $1.1 \%$ & $0.2 \%$ & $2.0 \%$ & $0.7 \%$ \\
\hline \multirow[t]{2}{*}{ Urban } & 125 & 493 & 495 & 624 & 296 & 54 & 446 & 2,533 \\
\hline & $1.0 \%$ & $0.5 \%$ & $1.1 \%$ & $2.1 \%$ & $2.0 \%$ & $0.4 \%$ & $0.6 \%$ & $0.9 \%$ \\
\hline \multirow[t]{2}{*}{ Uplforest } & 0 & 0 & 0 & 94 & 0 & 0 & 464 & 558 \\
\hline & $0 \%$ & $0 \%$ & $0 \%$ & $0.3 \%$ & $0 \%$ & $0 \%$ & $0.6 \%$ & $0.2 \%$ \\
\hline \multirow[t]{2}{*}{ Barren } & 0 & 0 & 0 & 0 & 0 & 0 & 0 & 0 \\
\hline & $0 \%$ & $0 \%$ & $0 \%$ & $0 \%$ & $0 \%$ & $0 \%$ & $0 \%$ & $0 \%$ \\
\hline Total & 13,021 & 106,638 & 43,759 & 29,410 & 14,476 & 14,572 & 75,714 & 297,590 \\
\hline
\end{tabular}

${ }^{a}$ Cottonwood and non-cottonwood types not differentiated

${ }^{b}$ Lumped with forest in analyses

c Lumped with agricultural cropland in analyses

Table 8 Land cover (area and \% of total) from 2006/08 aerial imagery

\begin{tabular}{|c|c|c|c|c|c|c|c|c|}
\hline \multirow[t]{2}{*}{ Land cover } & \multicolumn{8}{|c|}{ Area (ha) by segment } \\
\hline & 0 & 2 & 4 & 6 & 8 & 9 & 10 & Total $(0-10)$ \\
\hline \multirow[t]{2}{*}{ Forest and Woodland ${ }^{\mathrm{a}}$} & 1,629 & 19,576 & 12,895 & 911 & 2,257 & 171 & 5,191 & 42,630 \\
\hline & $12.5 \%$ & $18.3 \%$ & $29.5 \%$ & $3.1 \%$ & $15.6 \%$ & $1.2 \%$ & $6.9 \%$ & $14.3 \%$ \\
\hline \multirow[t]{2}{*}{ Shrubland $^{\mathrm{a}}$} & 788 & 7,221 & 1,918 & 73 & 540 & 93 & 1,116 & 11,749 \\
\hline & $6.0 \%$ & $6.8 \%$ & $4.4 \%$ & $0.2 \%$ & $3.7 \%$ & $0.6 \%$ & $1.5 \%$ & $3.9 \%$ \\
\hline \multirow[t]{2}{*}{ Grassland } & 2,790 & 24,346 & 6,682 & 2,570 & 1,480 & 61 & 747 & 38,676 \\
\hline & $21.4 \%$ & $22.8 \%$ & $15.3 \%$ & $8.7 \%$ & $10.2 \%$ & $0.4 \%$ & $1.0 \%$ & $13.0 \%$ \\
\hline \multirow[t]{2}{*}{ River } & 4,460 & 8,516 & 7,358 & 23,712 & 4,056 & 10,424 & 5,609 & 64,136 \\
\hline & $34.3 \%$ & $8.0 \%$ & $16.8 \%$ & $80.6 \%$ & $28.0 \%$ & $71.5 \%$ & $7.4 \%$ & $21.5 \%$ \\
\hline
\end{tabular}


Table 8 continued

\begin{tabular}{|c|c|c|c|c|c|c|c|c|}
\hline \multirow[t]{2}{*}{ Land cover } & \multicolumn{8}{|c|}{ Area (ha) by segment } \\
\hline & 0 & 2 & 4 & 6 & 8 & 9 & 10 & Total $(0-10)$ \\
\hline \multirow[t]{2}{*}{ Sandbar } & 95 & 98 & 181 & 12 & 46 & 84 & 422 & 938 \\
\hline & $0.7 \%$ & $0.1 \%$ & $0.4 \%$ & $<0.1 \%$ & $0.3 \%$ & $0.6 \%$ & $0.6 \%$ & $0.3 \%$ \\
\hline \multirow[t]{2}{*}{ Wetland } & 1,191 & 744 & 912 & 542 & 1,383 & 3,580 & 295 & 8,647 \\
\hline & $9.1 \%$ & $0.7 \%$ & $2.1 \%$ & $1.8 \%$ & $9.6 \%$ & $24.6 \%$ & $0.4 \%$ & $2.9 \%$ \\
\hline \multirow[t]{2}{*}{ Pond, lake } & 26 & 1,573 & 249 & 132 & 127 & 93 & 262 & 2,462 \\
\hline & $0.2 \%$ & $1.5 \%$ & $0.6 \%$ & $0.4 \%$ & $0.9 \%$ & $0.6 \%$ & $0.3 \%$ & $0.8 \%$ \\
\hline \multirow[t]{2}{*}{ Agriculture } & 1,873 & 43,765 & 10,771 & 140 & 4,322 & 12 & 59,784 & 120,667 \\
\hline & $14.4 \%$ & $40.9 \%$ & $24.6 \%$ & $0.5 \%$ & $29.9 \%$ & $0.1 \%$ & $79.0 \%$ & $40.5 \%$ \\
\hline \multirow[t]{2}{*}{ Woodlot } & 0 & 45 & 79 & 48 & 42 & 0 & 755 & 969 \\
\hline & $0 \%$ & $<0.1 \%$ & $0.2 \%$ & $0.2 \%$ & $0.3 \%$ & $0 \%$ & $1.0 \%$ & $0.3 \%$ \\
\hline \multirow[t]{2}{*}{ Plantedcw } & 0 & 0 & 31 & 98 & 39 & 1 & 0 & 168 \\
\hline & $0 \%$ & $0 \%$ & $0.1 \%$ & $0.3 \%$ & $0.3 \%$ & $<0.1 \%$ & $0 \%$ & $0.1 \%$ \\
\hline \multirow[t]{2}{*}{ Urban } & 134 & 786 & 2,673 & 1,065 & 175 & 43 & 1,036 & 5,912 \\
\hline & $1.0 \%$ & $0.7 \%$ & $6.1 \%$ & $3.6 \%$ & $1.2 \%$ & $0.3 \%$ & $1.4 \%$ & $2.0 \%$ \\
\hline \multirow[t]{2}{*}{ Uplforest } & 4 & 7 & 12 & 105 & 10 & 9 & 494 & 641 \\
\hline & $<0.1 \%$ & $<0.1 \%$ & $<0.1 \%$ & $0.4 \%$ & $0.1 \%$ & $0.1 \%$ & $0.7 \%$ & $0.2 \%$ \\
\hline \multirow[t]{2}{*}{ Barren } & 31 & 232 & 3 & 0 & 0 & 0 & 3 & 269 \\
\hline & $0.2 \%$ & $0.2 \%$ & $<0.1 \%$ & $0 \%$ & $0 \%$ & $0 \%$ & $<0.1 \%$ & $0.1 \%$ \\
\hline Total & 13,021 & 106,909 & 43,763 & 29,408 & 14,476 & 14,572 & 75,712 & 297,861 \\
\hline
\end{tabular}

${ }^{\text {a }}$ Cottonwood and non-cottonwood types were separated in land cover data. but are combined above

\section{References}

Angradi TR, Schweiger EW, Bologrien DW, Ismert P, Selle T (2004) Bank stabilization, riparian land use and the distribution of large woody debris in a regulated reach of the upper Missouri River, North Dakota, USA. River Research and Applications 20: 829-846

Bertoldi W, Drake NA, Gurnell AM (2011) Interactions between river flows and colonizing vegetation on a braided river: exploring spatial and temporal dynamics in riparian vegetation cover using satellite data. Earth Surface Processes and Landforms 36: 1474-1486

Bovee KD, Scott ML (2002) Effects of flow regulation on the upper Missouri River: implications for flood pulse restoration. Regulated Rivers: Research and Management 18:287-298

Bradley CE, Smith DG (1986) Plains cottonwood recruitment and survival on a prairie meandering river floodplain, Milk River, southern Albert and northern Montana. Canadian Journal of Botany 64:1433-1442

Bragg T, Tatschl A (1977) Changes in flood-plain vegetation and land use along the Missouri River from 1826 to 1972. Environmental Management 1(4):343-348

Coker EH, Hotchkiss RH, Johnson DA (2009) Conversion of a Missouri River dam and reservoir to a sustainable system: sediment management (1). Journal of the American Water Resources Association 45:815-827

Cooper DJ, Andersen DC, Chimner RA (2003) Multiple pathways for woody plant establishment on floodplains at local to regional scales. Journal of Ecology 91:182-196

Cordes LD, Hughes FMR, Getty M (1997) Factors affecting the regeneration and distribution of riparian woodlands along a northern prairie river: the Red Deer River, Alberta, Canada. Journal of Biogeography 24:675-695
Corenblit D, Steiger J, Gurnell AM, Tabacchi E, Roques L (2009) Control of sediment dynamics by vegetation as a key function driving biogeomorphic succession within fluvial corridors. Earth Surface Processes and Landforms 34:1790-1810

Dixon MD, Turner MG (2006) Simulated recruitment of riparian trees and shrubs under natural and regulated flow regimes on the Wisconsin River, USA. River Research and Applications 22:1057-1083

Dixon MD, Stromberg JC, Price JT, Galbraith H, Fremier AK, Larsen EW (2009) Potential effects of climate change on the upper San Pedro riparian ecosystem. Chapter 3, In: Stromberg, J C, Tellman B (eds.), Ecology and Conservation of the San Pedro River. University of Arizona Press, Tucson

Dynesius M, Nilsson C (1994) Fragmentation and flow regulation of river systems in the northern third of the world. Science 266(5186):753-762

Elliott CM, Jacobson RB (2006) Geomorphic Classification and Assessment of Channel Dynamics in the Missouri National Recreational River, South Dakota and Nebraska. U.S. Geological Survey, Scientific Investigations Report 2006-5313, p 66

Fenneman NM, Johnson DW (1946) Physiographic divisions of the conterminous U.S. U.S. Geological Survey special map series, scale $1: 7,000,000$

Finch DM, Ruggiero LF (1993) Wildlife and biological diversity in the Rocky Mountains and northern Great Plains. Natural Areas Journal 13:191-203

Florsheim JL, Mount JF, Chin A (2008) Bank erosion as a desirable attribute of rivers. Bioscience 58:519-529

Friedman JM, Osterkamp WR, Scott ML, Auble GT (1998) Downstream effects of dams on channel geometry and bottomland vegetation: regional patterns in the Great Plains. Wetlands 18:619-633

Funk JL, Robinson JW (1974) Changes in the Channel of the Lower Missouri River and Effects on Fish and Wildlife. Missouri 
Department of Conservation Aquatic Series No. 11. Jefferson City, p 52

Galat DL, Lipkin R (2000) Restoring the ecological integrity of great rivers: historical hydrographs aid in defining reference conditions for the Missouri River hydrosystem. Hydrobiologia 422(423):29-48

Galat DL, Berry CR Jr, Peters EJ, White RG (2005) Missouri River Basin. In: Benke AC, Cushing CE (eds) Rivers of North America. Elsevier, Oxford, pp 427-480

Gergel SE, Dixon MD, Turner MG (2002) Consequences of humanaltered floods: levees, floods, and floodplain forests along the Wisconsin River. Ecological Applications 12(6):1755-1770

Golet GH, Gardali T, Howell CA, Hunt J, Luster RA, Rainey W, Roberts MD, Silveira J, Swagerty H, Williams N (2008) Wildlife response to riparian restoration on the Sacramento River. San Francisco Estuary and Watershed Science 6(2):2-26

Graf WL (1999) Dam nation: A geographic census of American dams and their large-scale hydrologic impacts. Water Resources Research 35:1305-1311

Graf WL (2006) Downstream hydrologic and geomorphic effects of large dams on American rivers. Geomorphology 79:336-360

Hallberg GR, Harbaugh JM, Witinok PM (1979) Changes in the Channel Area of the Missouri River in Iowa, 1879-1976. Iowa Geological Survey Special Report Series Number 1, p 32

Hesse LW (1996) Floral and faunal trends in the middle Missouri River. In: Galat DL, Frazier AG (eds.), Science for floodplain management into the 21 st century. Vol. 3. Overview of the riverfloodplain ecology in the upper Mississippi River Basin, Kelmelis JA (ed.). U.S. Government Printing Office, Washington

Jacobson RB, Blevins DW, Bitner CJ (2009) Sediment regime constraints on river restoration-An example from the Lower Missouri River. In: James, LA, Rathburn, Whittecar GR (eds.), Management and Restoration of Fluvial Systems with Broad Historical Changes and Human Impacts. Geological Society of America Special Paper 451:1-22

Jacobson RB, Elliott CM, Huhmann BL (2010) Development of a Channel Classification to Evaluate Potential for Cottonwood Restoration, Lower Segments of the Middle Missouri River, South Dakota and Nebraska. U.S. Geological Survey Scientific Investigations Report 2010-5208, p 38

Jacobson RB, Janke TP, Skold J (2011) Hydrologic and geomorphic considerations in restoration of river-floodplain connectivity in a highly altered river system, Lower Missouri River, USA. Wetlands Ecology and Management 19:295-316

Johnson WC (1992) Dams and riparian forests: case study from the upper Missouri River. Rivers 3(4):229-242

Johnson WC (1994) Woodland expansion in the Platte River, Nebraska: patterns and causes. Ecological Monographs 64:45-84

Johnson WC (1998) Adjustment of riparian vegetation to river regulation in the Great Plains, USA. Wetlands 18:608-618

Johnson WC (2002) Riparian vegetation diversity along regulated rivers: contribution of novel and relict habitats. Freshwater Biology 47:749-759

Johnson WC, Burgess RL, Keammerer WR (1976) Forest overstory and environment along the Missouri River in North Dakota. Ecological Monographs 46:59-84

Johnson WC, Dixon MD, Scott ML, Rabbe L, Larson G, Volke M, Werner B (2012) Forty years of vegetation change on the Missouri River floodplain. BioScience 62(2):123-135

Karrenberg S, Edwards PJ, Kollmann (2002) The life history of Salicaceae in the active zone of floodplains. Freshwater Biology 47:733-748

Kondolf GM (1997) Hungry water: effects of dams and gravel mining on river channels. Environmental Management 21:533-551

Michalková M, Piégay H, Kondolf GM, Greco SE (2010) Lateral erosion of the Sacramento River, California (1942-1999), and responses of channel and floodplain lake to human influences. Earth Surface Processes and Landforms 36:257-272

Missouri River Commission (MRC) (1895) Map of the Missouri River from its mouth to Three-Forks Montana, in eighty four sheets. Missouri River Commission, Washington, 1:63,360 scale

Molles MC Jr, Crawford CS, Ellis LM, Valett HM, Dahm CN (1998) Managed flooding for riparian ecosystem restoration. BioScience 48(9):749-756

Murray AB, Knaapen AF, Tal M, Kirwan ML (2008) Biomorphodynamics: physical-biological feedbacks that shape landscapes. Water Resources Research 44(11):W11301. doi:10.1029/2007 WR006410

National Research Council (NRC) (2002) The Missouri River Ecosystem: Exploring the Prospects for Recovery. National Academy Press, Washington, p 175

National Research Council (NRC) (2011) Missouri River Planning: Recognizing and Incorporating Sediment Management. National Academy Press, Washington, p 152

Nilsson C, Berggren K (2000) Alteration of riparian ecosystems caused by river regulation. BioScience 50(9):783-792

Nilsson C, Reidy CA, Dynesius M, Revenga C (2005) Fragmentation and flow regulation of the world's large river systems. Science 308:405-408

Ollero AF (2010) Channel changes and floodplain management in the meandering middle Ebro River. Spain. Geomorphology 116(3-4): $247-260$

Poff NL, Allan JD, Bain MB, Karr JR, Prestegaard KL, Richter BD, Sparks RE, Stromberg JC (1997) The natural flow regime: a paradigm for river conservation and restoration. BioScience 47:769-784

Poff NL, Olden JD, Merritt DM, Pepin DM (2007) Homogenization of regional river dynamics by dams and global biodiversity implications. Proceedings of the National Academy of Sciences of the USA 104:5732-5737

Reily PW, Johnson WC (1982) The effects of altered hydrologic regime on tree growth along the Missouri River in North Dakota. Canadian Journal of Botany 60:2410-2423

Revenga C, Murray S, Abramovitz J, Hammond A (1998) Watershed of the World: Ecological Value and Vulnerability. Worldwatch Institute, Washington

Ricketts TH, Dinerstein E, Olson DM, Loucks CJ, Eichbaum W, DellaSalla D, Kavanaugh K, Hedao P, Hurly PT, Carney KM, Abell R, Walters S (1999) Terrestrial ecoregions of North America: A conservation assessment. Island Press, Washington

Rood SB, Mahoney JM (1990) Collapse of riparian poplar forests downstream from dams in western prairies: probable causes and prospects for mitigation. Environmental Management 14:451-464

Rood SB, Samuelson GM, Braatne JH, Gourley CR, Hughes FMR, Mahoney JM (2005) Managing river flows to restore floodplain forests. Frontiers in Ecology and the Environment 3(4):193-201

Rood SB, Goater LA, McGill KM, Braatne JH (2011) Sand and sandbar willow: a feedback loop amplifies environmental sensitivity at the riparian interface. Oecologia 165:31-40

Schmidt JC, Wilcock PR (2008) Metrics for assessing the downstream effects of dams. Water Resources Research 44:W04404. doi: 10.1029/2006WR005092

Schneiders RK (1999) Unruly River. Two Centuries of Change along the Missouri. University Press of Kansas, 314

Scott ML, Auble GT, Dixon MD, Johnson WC, Rabbe LA Long-term cottonwood forest dynamics on the upper Missouri River. River Res Appl (in press)

Scott ML, Friedman JM, Auble GT (1996) Fluvial process and the establishment of bottomland trees. Geomorphology 14:327-339

Scott ML, Auble GT, Friedman JM (1997) Flood dependency of cottonwood establishment along the Missouri River, Montana, USA. Ecological Applications 7(2):677-690 
Shields DF, Simon A, Steffen LJ (2000) Reservoir effects on downstream river channel migration. Environmental Conservation 27(1):54-66

Thogmartin WE, Gallagher M, Young N, Rohweder JJ, Knutson MG (2009) Factors associated with succession of abandoned agricultural lands along the lower Missouri River, USA. Restoration Ecology 17:290-296

U.S. Army Corps of Engineers (USACE) (1990) Lake Sakakawea Headwaters Aggradation Study, Sept. 1990

U.S. Army Corps of Engineers (USACE) (1999) Missouri River Oahe Dam to Big Bend Dam Aggradation Assessment. MRD Sediment Memorandum \#22

U.S. Army Corps of Engineers (USACE) (2000) Garrison Project Downstream Channel and Sediment Trend Study Update. MRD Sediment Memorandum \#16A, March 2000

U.S. Army Corps of Engineers (USACE) (2002) Draft Supplemental Environmental Impact Statement, Missouri River Fish and Wildlife Mitigation Project, U.S. Army Corps of Engineers, Northwestern Division: Missouri River Basin. Omaha, NE
U.S. Army Corps of Engineers (USACE) (2004) Missouri River Stage Trends. RCC Technical Report A-04. Reservoir Control Center, U.S. Army Corps of Engineers, Northwestern Division: Missouri River Basin, Omaha

U.S. Army Corps of Engineers (USACE) (2011) Final Programmatic Environmental Impact Statement for the Mechanical and Artificial Creation and Maintenance of Emergent Sandbar Habitat in the Riverine Segments of the Upper Missouri River. U.S. Army Corps of Engineers, Omaha District, Omaha, NE

U.S. Fish and Wildlife Service (USFWS) (2003) Amendment to the 2000 Biological Opinion on the Operation of the Missouri River Main Stem Reservoir System, Operation and Maintenance of the Missouri River Bank Stabilization and Navigation Project, and Operation of the Kansas River Reservoir System. Denver, CO and Fort Snelling, MN

Williams P, Wolman G (1984) Downstream effects of dams on alluvial rivers. U.S. Geological Survey Professional Paper 1286. U.S. Government Printing Office, Washington, p 81 